\title{
Integrating climate models into hydrological modelling: What's going on in Brazil?
}

\section{Integração de modelos de clima na modelagem hidrológica: o que está acontecendo no Brasil?}

\author{
Pablo Borges de Amorim ${ }^{1 *}$ (D) and Pedro Luiz Borges Chaffe ${ }^{1}$ (D) \\ ${ }^{1}$ Universidade Federal de Santa Catarina, Florianópolis, SC, Brasil \\ E-mails: borgesdeamorim.pablo@gmail.com (PBA), pedro.chaffe@ufsc.br (PLBC)
}

Received: November 20, 2018 - Revised: April 06, 2019 - Accept: May 11, 2019

\begin{abstract}
Studies integrating climate modelling output into hydrological modelling have grown substantially in the last two decades worldwide; however, there has not been a systematic review about those applications in the Brazilian territory. The aim of this study is to identify how the scientific community has been dealing with the topic in Brazil. The study is based on a systematic review of available peer-reviewed literature. We identify regions and socioeconomic sectors of interest and propose a method to evaluate the methodological consistency of the studies with the current state-of-the-art. The review shows that the topic has grown substantially in this decade, reaching 63 documents until 2018. The sectors under highest concern are the hydropower and the drinking water supply. The Paraná and Atlântico Nordeste Oriental hydrographic regions received great attention; whereas the Atlântico Sudeste did not. In terms of methodology, the use of multi-model ensemble leaves room for improvement. The results suggest a lack of human resources and access to computational infrastructure to handle climate data. Given the current challenges that Brazilian science is facing, we suggest the synchronization of efforts among research institutions. This systematic review provides information to help guiding decision makers to improve the topic in Brazil.
\end{abstract}

Keywords: Climate models; Hydrological models; Systematic review.

\section{RESUMO}

Estudos que integram modelagem climática em modelagem hidrológica têm crescido substancialmente nas últimas duas décadas em todo o mundo; entretanto, pouco se sabe sobre estes no território brasileiro. O objetivo deste estudo é identificar como a comunidade científica tem lidado com o tema no Brasil. O estudo baseia-se numa revisão sistemática da literatura revisada por pares disponível. Identificamos regiões e setores socioeconômicos de interesse e propomos um método para avaliar a consistência metodológica dos estudos com o atual estado-da-arte. A análise mostra que o tema cresceu substancialmente nesta década, abrangendo 63 documentos até 2018. Os setores de maior interesse são o de energia hidrelétrica e de abastecimento de água potável. As regiões hidrográficas do Paraná e do Atlântico Nordeste Oriental receberam grande atenção; enquanto a região Atlântico Sudeste pouca. Em termos de metodologia, o uso do conjunto de multi-modelos deixa espaço para melhorias. Os resultados sugerem limitações em capacidade técnica e em acesso à infraestrutura computacional para lidar com dados climáticos. Diante dos atuais desafios que a ciência brasileira enfrenta, sugerimos a sincronização de esforços entre instituições de pesquisa. Esta revisão sistemática fornece informações que podem ajudar os tomadores de decisão em ações de aprimoramento do tema no Brasil.

Palavras-chave: Modelos de clima; Modelos hidrológicos; Revisão sistemática. 


\section{INTRODUCTION}

The Brazilian National Plan for Climate Change Adaptation (Plano Nacional de Adaptação à Mudança do Clima - PNA) establishes among its objectives the improvement of the climate projections and the support to incorporate climate change information into adaptation plans (BRASIL, 2016). At the same time, the Projeto Legado (ANA, 2017) foresees the use of climate change scenarios as subsidy for the National Strategic Plan for Water Security. To achieve those goals, the first step is to assess how the scientific community is dealing with the issue in Brazil. Studies integrating climate change information into hydrological modelling have grown substantially in the last two decades worldwide (KUNDZEWICZ et al., 2018); however, there has not been a systematic review about them in the Brazilian territory.

Borges and Chaffe (2019) conducted a synthesis assessment about the impacts of climate change on the Brazilian water resources. They concluded that the recommended use of multi-model ensemble has been rarely applied. Nevertheless, there is a substantial consensus in the literature about potential change in the availability of water resources in Brazil, such as changes into a drier hydrological regime. Here, we extend the work of Borges and Chaffe (2019) with a review of the current state-of-the-practice of the integration of climate model outputs into hydrological models in Brazil. The study is based on a systematic review of all available peer-reviewed literature classified by regions and socioeconomic sectors of interest. We evaluate the methodological consistency of those studies with the current state-of-the-art, identify their strengths and limitations, and discuss how research institutions can improve their practices. Assessing how the scientific community is dealing with the use of climate information in hydrological modelling is a crucial step to understand the challenges and opportunities for the improvement of the topic in Brazil.

\section{MATERIALS AND METHODS}

\section{Paper selection and systematic review}

A comprehensive literature search was carried out in order to identify peer-reviewed scientific articles that integrate climate model outputs into hydrological modelling in the Brazilian territory. We used three science databases: Scopus, Web of Science and Google Scholar (HARZING; ALAKANGAS, 2016). We also considered the Scientific Electronic Library Online (SciELO) and the following Brazilian scientific journals: Anais da Academia Brasileira de Ciências (AABC), Brazilian Journal of Water Resources, Ciência e Agrotecnologia (CAGRO), Revista Brasileira de Climatologia, Revista Brasileira de Engenharia Agrícola e Ambiental (AGRIAMBI), Revista Brasileira de Meteorologia (RBMet) and Revista Engenharia Agrícola (EAGRI).

The search considered articles published until December 2018. Articles written in English and Portuguese were included. Publications such as book chapters, doctoral dissertations and conference papers were not taken into account. To find the documents, Boolean functions were applied to match the following keywords in the title, abstract or keywords: ['climate model' OR gcm OR aogcm OR oagcm OR 'climate change'] AND [hydrologic OR hydrology OR hydrological OR hydraulic OR 'rainfall-runoff']
AND [Brazil]. Initially the search yielded hundreds of documents, but only 63 were considered relevant for the purpose of this study. The documents are listed in the Table 1, wherein sixteen were published in Brazilian scientific journals.

The systematic review is organized in three major groups that embraces eight aspects for analysis (Figure 1). The year of publication and Impact Factor (IF, Journal Citation Reports of the Institute for Scientific Information) indicate the level of concern of the scientific community. The second group corresponds to the interest, which is divided in hydrographic region, sector and purpose. The third group corresponds to the approach adopted in the studies: i) the quantity and version of the climate models (General Circulation Models - GCM or Earth System Models ESM), ii) the application of regionalization techniques, and iii) type and quantity of hydrological models.

\section{Level of comprehensiveness of the studies}

The considerable quantity of documents found provides plausible messages of the state-of-the-practice in applying climate scenarios in hydrological impact assessments in Brazil. The methodology used to evaluate the 'level of comprehensiveness' of a certain study was inspired in Mastrandrea et al. (2011) - the same one used in the Intergovernmental Panel on Climate Change's (IPCC) Fifth Assessment Report (AR5) -, which depends on three aspects: i) theoretical foundation, ii) data used, and iii) sophistication of the modelling procedure. Each aspect is scored from 1 to 5 , which are associated with the terms: very limited, limited, medium, fairly robust or robust. This analysis considered only studies addressing the impacts of climate change on water resources (i.e., 48 articles, see section Purpose).

\section{Theoretical foundation}

The theoretical foundation aspect refers to the regionalization procedure adopted. There are several ways to include projections of climate change in hydrological models. The most plausible and physically consistent representations of climate due to anthropogenic activity are those provided by climate models (WILBY et al., 2009). Due to the coarse resolution, GCMs are often not able to represent spatiotemporal variability of climatic variables (e.g., rainfall) at the scale required for hydrological studies. The application of regionalization techniques is therefore recommended (FOWLER; BLENKINSOP; TEBALDI, 2007; MARAUN et al., 2010). We defined regionalization as downscaling and bias correction (BC). The downscaling is divided into two families, the dynamical (Regional Climate Model - RCM) and the statistical (Empirical Statistical Downscaling - ESD).

The RCMs have the same principles of GCMs in representing the dynamical and physical processes of the terrestrial system but in a much finer resolution and limited domain area. The ESD relies on the principle that local weather is a function of large-scale atmospheric patterns. A statistical function is used to estimate e.g., rainfall based on the large-scale relative humidity and zonal wind data at the $500 \mathrm{hPa}$ level. The $\mathrm{BC}$ is often mistaken by ESDs since both are based on empirical data. But in $\mathrm{BC}$ the 
Table 1. List of articles.

\begin{tabular}{|c|c|}
\hline Abramopoulos, Rosenzweig and Choudhury (1988) & Pereira, Moraes and Uvo (2014) \\
\hline Marengo et al. (1994) & Popescu, Brandimarte and Peviani (2014) \\
\hline Krol et al. (2001) & Ribeiro Neto et al. (2014) \\
\hline Medeiros (2003) & Silveira et al. (2014) \\
\hline Tucci et al. (2003) & Adam et al. (2015) \\
\hline Araújo et al. (2004) & Arroio Junior and Mauad (2015) \\
\hline Rosenzweig et al. (2004) & Ramos Iensen, Bauer Schultz and Santos (2015) \\
\hline Coelho et al. (2006) & Mohor et al. (2015) \\
\hline Krol et al. (2006) & Oliveira, Pedrollo and Castro (2015a) \\
\hline Krol and Bronstert (2007) & Oliveira, Pedrollo and Castro (2015b) \\
\hline Mello et al. (2008) & Siqueira Júnior, Tomasella and Rodriguez (2015) \\
\hline Block et al. (2009) & Valério and Júnior (2015) \\
\hline Lima and Alves (2009) & Viola et al. (2015) \\
\hline Montenegro and Ragab (2010) & Alvarenga et al. (2016) \\
\hline Gondim et al. (2011) & Ho, Thompson and Brierley (2016) \\
\hline Gosling et al. (2011) & Lamparter et al. (2016) \\
\hline Nóbrega et al. (2011) & De Queiroz et al. (2016) \\
\hline Rivarola Sosa et al. (2011) & Ribeiro Júnior, Zuffo and Silva (2016) \\
\hline Alves, Campos and Servain (2012) & Ribeiro Neto et al. (2016) \\
\hline Cook, Zeng and Yoon (2012) & Sorribas et al. (2016) \\
\hline Hirata and Conicelli (2012) & Tejadas et al. (2016) \\
\hline Kwon et al. (2012) & Fernandes et al. (2017) \\
\hline Marengo et al. (2012) & Guimberteau et al. (2017) \\
\hline Montenegro and Ragab (2012) & Melo and Wendland (2017) \\
\hline Adam and Collischonn (2013) & Mendes, Beluco and Canales (2017) \\
\hline Braga et al. (2013) & Mohor and Mendiondo (2017) \\
\hline Kruk, Vendrame and Chou (2013) & De Oliveira et al. (2017) \\
\hline Perazzoli, Pinheiro and Kaufmann (2013) & Pinheiro, Van Lier and Bezerra (2017) \\
\hline Pinheiro, Graciano and Kaufmann (2013) & Silveira, Souza Filho and Vasconcelos Júnior (2017) \\
\hline Bravo et al. (2014) & Gondim et al. (2018) \\
\hline Fill et al. (2013) & Zaninelli et al. (2018) \\
\hline Melo, Marin and Wendland (2014) & \\
\hline
\end{tabular}
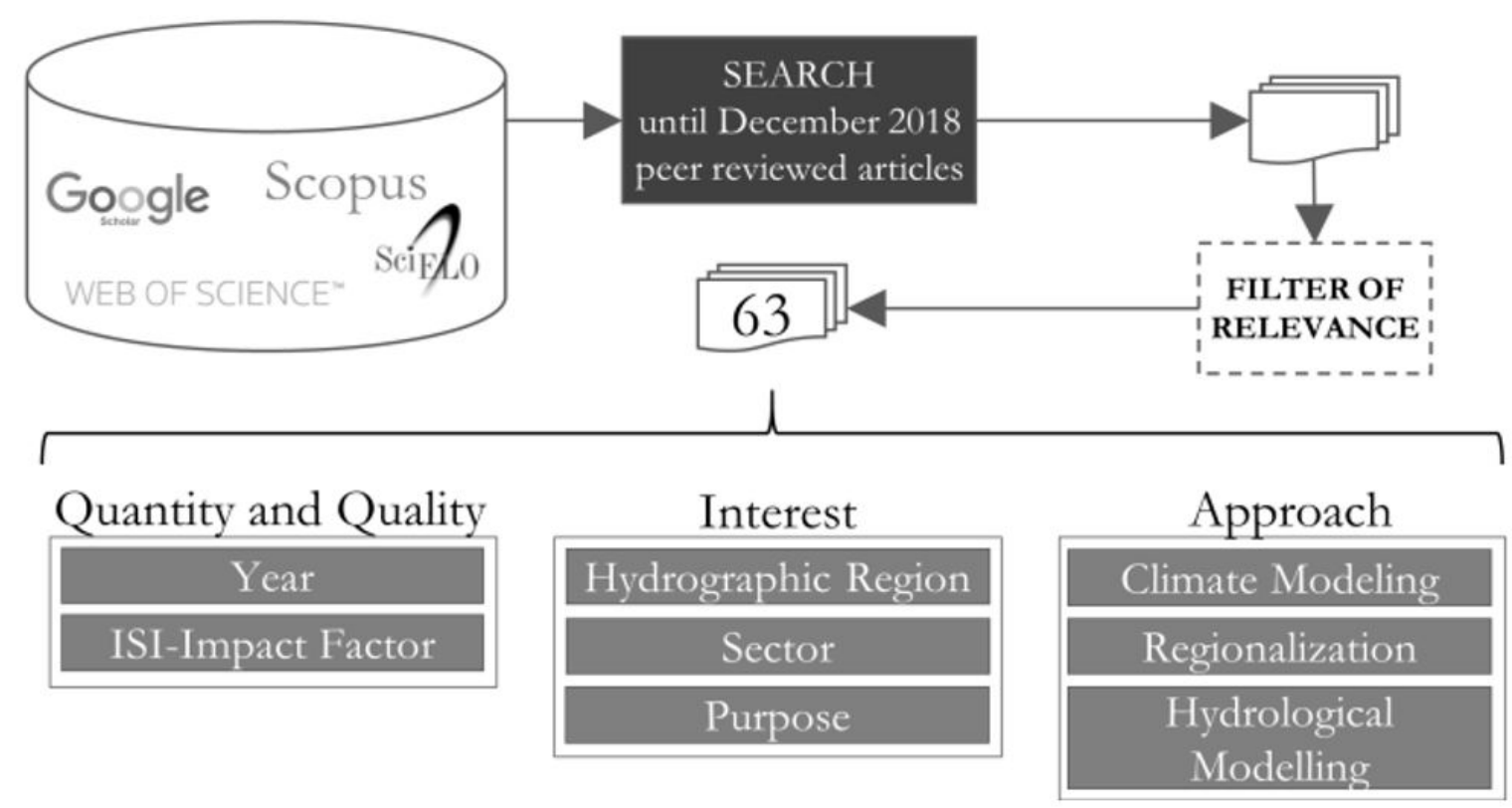

Figure 1. Flowchart of the search and characterization of the systematic review. 
predictor variable is the same as the target variable. That is, a transfer function is used to generate e.g., local rainfall from the precipitation simulated by a GCM. BC does not consider physical arguments and is thus less plausible than downscaling techniques. We found numerous studies in Brazil applying BC in combination with RCM outputs or even as a means of replacing downscaling. Although the application of $\mathrm{BC}$ is controversial in hydrological impact assessments (EHRET et al., 2012), we cannot neglect this step (TEUTSCHBEIN; SEIBERT, 2012) and thus we assume BC as a simple form of regionalization. The pattern scaling technique is also often applied in hydrological impact studies (FOWLER; BLENKINSOP; TEBALDI, 2007), for instance in Brazil (i.e., BRAVO et al., 2014; NÓBREGA et al., 2011; PERAZZOLI; PINHEIRO; KAUFMANN, 2013). Due to the degree of sophistication, the pattern scaling is classified as ESD. For more details on the definitions adopted here see Maraun et al. (2010).

Table 2 describes the scoring criteria adopted to classify the articles. The study that uses only GCM outputs without any regionalization is considered less theoretically sound and is given a score of 1. GCM combined with a very simple BC (e.g., Delta Change Factor - DCF), counts 2. When more sophisticated BC is applied (e.g., Quantile Mapping - QM), the study is given a score of 3. Studies integrating a GCM with either a RCM or a ESD gets 4 scores. A maximum scoring study should consider: i) the GCM outputs integrated with RCM followed by a BC, or ii) GCM with RCM in addition to GCM with ESD.

Data used

A common approach in sampling all aspects of model uncertainties in climate impact assessments is the multi-model ensemble (MME). The MME is based on the assertion that no model performs better than another. The combination of several climate models has the potential to increase the skill, reliability and consistency of projections. The application of MME in impact assessments does not only benefit from error compensation and quantification of uncertainties, but also from its greater consistency and reliability (TEBALDI; KNUT'TI, 2007). The MME approach is strongly recommended in hydrological impact assessments (KUNDZEWICZ et al., 2018). This category is dedicated to the quantity of GCM members used. Studies using a single GCM receive 1 score. Two GCMs obtain 2 scores. From three to nine GCMs, the study counts 3. From ten to nineteen GCMs, 4 scores. From twenty GCMs, the score is 5 .

Sophistication of the modelling procedure

The criteria adopted was the version of the GCMs and the level of sophistication, and the quantity of the regionalization methods (REG) and hydrological models (HM). This group was thus divided into five sub-aspects: GCM, RCM, ESD, BC e HM. GCMs belonging to the Coupled Model Intercomparison Project Phase 3 (CMIP3) receive 4 scores, while the last version (i.e., CMIP5) gets 5. GCM versions prior to CMIP3 receive 2 scores. The CMIP3's GCMs show a significant progress from previous versions. The version used in most studies of the Fourth Assessment Report (AR4) of the IPCC embraces the dynamics of important physical components of the climate system. The most relevant advances are: i) improvement of dynamical core; ii) increase of vertical and horizontal resolutions; iii) incorporation of process such as land surface and sea-ice, and iv) improvement of parametrizations (RANDALL; WOOD, 2007). The CMIP5 includes the representation of various biogeochemical cycles

Table 2. Aspects and scores for rating the level of comprehensiveness of the studies.

\begin{tabular}{|c|c|c|c|}
\hline Aspect & Sub-aspect & Condition & Score \\
\hline \multirow[t]{5}{*}{ Theoretical foundation } & & raw GCM & 1 \\
\hline & & GCM->DCF & 2 \\
\hline & & GCM->QM & 3 \\
\hline & & GCM-> RCM or GCM->ESD & 4 \\
\hline & & GCM- $>$ RCM- $>$ BC or GCM- $>$ RCM + GCM- $>$ ESD & 5 \\
\hline \multirow[t]{5}{*}{ Data Used } & & $1 \mathrm{GCM}$ & 1 \\
\hline & & 2 GCMs & 2 \\
\hline & & 3-9 GCMs & 3 \\
\hline & & 10-19 GCMs & 4 \\
\hline & & $\geq 20 \mathrm{GCMs}$ & 5 \\
\hline \multirow[t]{8}{*}{ Sophistication of the modelling procedure } & GCM & Before CMIP3 & 3 \\
\hline & & CMIP3 & 4 \\
\hline & & CMIP5 & 5 \\
\hline & REG & DCF or DA & $1^{*}$ \\
\hline & & QM & $2^{*}$ \\
\hline & & RCM or ESD & $3^{*}$ \\
\hline & $\mathrm{HM}$ & SEE & $2^{*}$ \\
\hline & & Physically-based models & $3 *$ \\
\hline
\end{tabular}

GCM: General Circulation Model; DCF: Delta Change Factor; DA: Direct approach; QM: Quantile-Mapping; RCM: Regional Climate Model; ESD: Empirical Statistical Downscaling; BC: Bias Correction; CMIP: Coupled Model Intercomparison Project; REG: Regionalization; HM: Hydrological Modelling; SEE: simple empirical estimations. *If more than one model is used, than add 1 score per extra model. 
(FLATO; MAROTZKE, 2013) which are key for better representing e.g., the carbon cycle (TAYLOR; STOUFFER; MEEHL, 2012). Although the last version includes more comprehensive models, the enhancement in estimating precipitation over South America is questionable (BLÁZQUEZ; NUÑEZ, 2013; GULIZIA; CAMILLONI, 2015; TORRES; MARENGO, 2014). The difference between both CMIP versions is thus only 1 score.

We did not consider any differentiation among the types of RCM. Any study that adopts one RCM get 3 scores no matter the model. If the study adopted more than one, then 1 score is added per RCM. For instance, studies considering three RCMs get 5 scores $(3+1+1=5)$. The same criterion is valid for ESD, BC e HM. Exceptions are studies considering less sophisticated methods: i) the DCF for BC receives 1 score and, ii) simple empirical estimations (SEE) for HM (i.e., simple water budget, Thornthwaite-Mather and Artificial Neural Network) receives 2 scores, when adopted alone. The final score of the 'sophistication of modelling procedure' aspect is the arithmetic mean of the scores obtained among the sub-aspects (GCM, RCM, ESD, BC e HM). If the study did not apply any regionalization technique, the

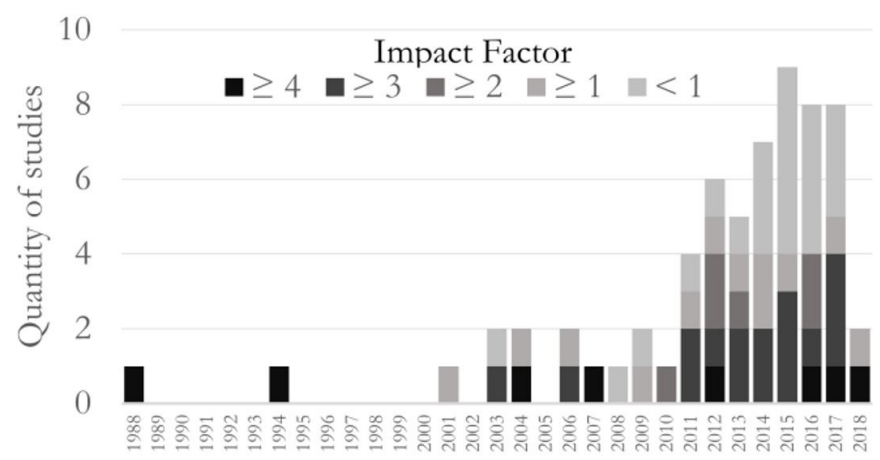

Figure 2. Quantity of articles per year and respective IF. respective sub-aspect is not counted in the calculation. In case of an arithmetic mean resulting in a decimal number, the value is rounded to the nearest integer. All data regarding the articles and respective scoring are included as a spreadsheet file in the Supplementary Material (Table S1).

\section{RESULTS AND DISCUSSION}

\section{Quantity and quality of the publications}

The first scientific article about the subject in Brazil was published at the end of the 80s by Abramopoulos et al. (1988). At that time, the subject was novel and studies constituted mainly of evaluation of model coupling between land-surface and atmosphere at the global scale, such as Marengo et al. (1994). More than one decade later, Krol et al. (2001) starts the era of regional studies addressing the impact of climate change on water resources in Brazil. Since 2011, substantial increase in the quantity of publications per year is observed (Figure 2). The year of 2015 is the most productive with nine publications. The first articles are associated with high IF $(\geq 4)$ due to the originality at that time. The increasing amount of publications with significant IF $(\geq 2)$ shows the great interest on the subject in the current decade. Surprisingly, in 2018 only two articles were published.

\section{Interest}

Hydrographic regions

Figure 3 illustrates the hydrographic regions and respective quantity of studies by sector. It is important to note that in some cases more than one hydrographic region and/or sector is considered

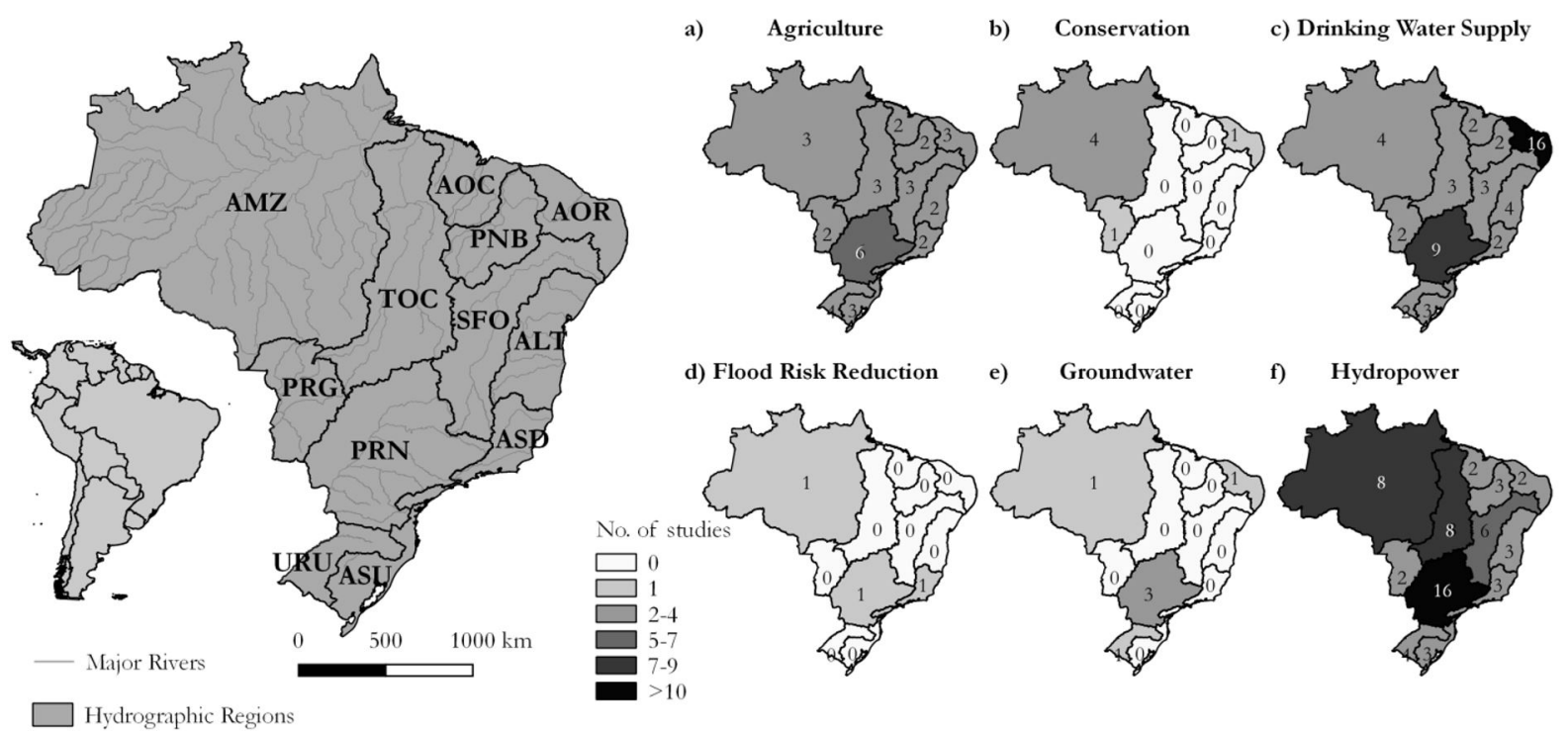

Figure 3. Quantity of studies per hydrographic region and socioeconomic sector of interest. According to ANA (2017), the hydrographic regions are: Amazônica (AMZ); Atlântico Nordeste Oriental (AOR); Atlântico Nordeste Ocidental (AOC); Atlântico Sudeste (ASD); Atlântico Leste (ALT); Atlântico Sul (ASU); Paraguai (PRG); Parnaíba (PNB); Paraná (PRN); São Francisco (SFO); Tocantins-Araguaia (TOC); Uruguai (URU). 
in the same study. Most of the papers (i.e., twenty-eight studies) focused on the Paraná (PRN) hydrographic region. The main interest is the hydropower sector (sixteen studies) followed by the drinking water supply (nine studies) and the agriculture (six studies). The PRN region has the greatest economic development of Brazil and is strongly dependent on energy supply from hydropower plants. The growth of urban areas, such as São Paulo, has generated great pressure on water resources and increased water use conflicts. With the highest energy and water demand in the country (BRASIL, 2006a), it is not a surprise that most of the studies addressed the PRN.

The second region of highest interest is the Atlântico Nordeste Oriental (AOR), with eighteen studies. This region includes the Brazilian semi-arid and has the drinking water supply as the sector under highest concern (sixteen studies). The drinking water supply in the semi-arid is strongly dependent on artificial reservoirs, which are highly vulnerable to alterations in the climatic conditions (BRASIL, 2006b)

Worldwide known for its water availability and biodiversity, the Amazônica (AMZ) region tends to be the focus when it comes to climate change (NOBRE et al., 2016). We found fifteen studies about the AMZ. The most relevant sectors in this region are hydropower (eight studies), drinking water supply and conservation (both with four studies). The studies available are in accordance with the current issues in the AMZ region. The largest and most biodiverse tropical rainforest in the world is under great concern. Recent socioeconomic growth in the region has brought about discussions on the traditional development models based on agriculture/pasture expansion and large inundated areas for hydropower production. Understanding the impacts of land cover and climate change on the water availability is crucial to guide proper adaptation strategies (BRASIL, 2006c).

The Tocantins-Araguaia (TOC) has great vocation for irrigated agriculture and hydropower production (BRASIL, 2006d). Ten studies considered the TOC region. The hydropower sector is of interest in eight studies. Agriculture and drinking water supply were addressed in three studies each.

The São Francisco (SFO) is known for the growth of agriculture, the intended revitalization of navigation, the increase in energy demand and the interbasin water transfer projects. The multiple uses of water resources in this region can induce to conflicts among the different sectors (BRASIL, 2006e). Out of the eight studies about the region, six of them addressed hydropower production. Agriculture and drinking water supply were considered in three studies each.

As part of the La Plata basin, the Uruguai (URU) has great importance for the country due to its agroindustry and hydropower potential (BRASIL, 2006f). The number of studies in the region (eight articles) corroborates that, agriculture and hydropower sectors are under concern in four studies each.

The Atlântico Leste (ALT) is characterized by high population density. Economic activities are mainly related to petrol-chemical industry, tourism and sugarcane and cacao production (BRASIL, $2006 \mathrm{~g})$. Five studies were found. The drinking water supply sector is under concern in four of them.

The Atlântico Sul (ASU) is notable for its significant population contingent, for economic development and for its importance for tourism (BRASIL, 2006h). We found five studies in the region. Agriculture and drinking water supply were addressed in three studies each.

The Paraguai (PRG) includes one of the largest wetlands on the planet, the Pantanal. Conservation of biodiversity is under high concern in the region, especially due to the recent expansion of pasture and agriculture (BRASIL, 2006i). Four studies addressed the PRG region. The sectors of interest are agriculture and drinking water supply (three studies each). Conservation was considered in one study.

Even with the high population and economic importance, the Atlântico Sudeste (ASD) presented only four studies. The region has serious problems with water supply (BRASIL, 2006j). Two articles regarded the water supply sector. Also known for flood-related disasters (CEPED UFSC, 2013), one study tackled the flood risk reduction sector in the region.

The main issues in the Parnaíba (PNB) are droughts, urban water supply, irrigation and conflicts of use (BRASIL, 2006k). The region was contemplated in three studies, wherein the agriculture and drinking water supply sectors were addressed in two studies each.

The Atlântico Nordeste Ocidental (AOC), where water criticality and deforestation are the main issues (BRASIL, 20061), was contemplated in two studies only. The agriculture and drinking water supply sectors were addressed in two studies each.

\section{Socioeconomic Sectors}

One of the main economic activities of Brazil, the agriculture was addressed in thirteen studies (Figure 3a). The agriculture sector is responsible for most of the water use in the country and there is a great potential for expansion through irrigation (ANA, 2013). Despite the territorial extension and favorable physical factors, alterations on climatic conditions can significantly affect the water availability for this sector.

The conservation sector was considered in six studies (Figure 3b). Understanding the impacts of vegetation replacement on the water cycle is crucial to establish best practices for land and water conservation (STERLING; DUCHARNE; POLCHER, 2012). Land use and cover change (LUCC) directly affects the water availability and quality of river basins. Runoff changes are often attributed to LUCC rather than rainfall variability (CHAGAS; CHAFFE, 2018). Besides the direct influence on the water cycle, climate determines natural land cover as well (SALAZAR; NOBRE; OYAMA, 2007). Assessing the vulnerability of water resources to non-climatic drivers, such as LUCC, and related feedback effects with regional climate is crucial to determine effective adaptation strategies (JIMÉNEZ CISNEROS et al., 2014).

The drinking water supply sector is of the highest interest (twenty-seven studies, Figure 3c). Issues on water supply in Brazil are mainly related to the quantity in the semi-arid region and quality in urban areas. Recent climatic conditions have significantly affected the water supply in metropolitan regions such as São Paulo and Rio de Janeiro (ANA, 2014). Although COELHO et al., (2016) attributed recent rainfall deficits to natural climate variability, the impacts of anthropogenic-induced climate change is still little known. 
Floods are under high concern worldwide (IPCC, 2012). In the last two decades, nearly 9 thousand disasters related to extreme hydrological events were registered in Brazil. Direct and indirect damages were estimated in $\mathrm{R} \$ 72$ billion ( $\sim \mathrm{US} \$ 22$ billion, CEPED UFSC; WORLD BANK, 2016). Despite the great importance in terms of socioeconomic impacts, the flood risk reduction sector - in the context of climate change - was addressed in three studies only (Figure 3d).

The groundwater sector is of great importance in Brazil. According to (ANA, 2010), 39\% of the municipalities depend exclusively on this water resource. Groundwater can be strategic in terms of adaptation to surface water scarcity, therefore understanding its vulnerability to climate change is crucial (JIMÉNEZ CISNEROS et al., 2014). There were only six studies that considered the impacts of climate change on the groundwater (Figure 3e).

The hydropower sector was the main focus of twenty-nine studies (Figure 3f). Hydroelectricity is approximately $61 \%$ of the total installed capacity in the country (ANEEL, 2017). The recent water crisis has raised the concern about the impacts of climate change in the Brazilian hydropower sector (ANA, 2014). The operation of all power plants in the country is centralized in the National System Operator (Operador Nacional do Sistema - ONS). The distinct climatic regions across the country and conflicts among multiple-uses represents an enormous challenge for the establishment of robust operational plans under climate change (SILVEIRA; SOUZA FILHO; VASCONCELOS JÚNIOR, 2017)

\section{Purpose}

Forty-eight articles focused on the application of models to assess the impacts of climate change (Figure 4). The evaluation of methods was the main focus in eleven studies, whereas four aimed at model development. The disparity of purpose is consistent with the scientific context. In general, most scientific studies tend to address the application of consolidated methods in different locations and/or circumstances. The evaluation of methods is primordial for the development of robust and consistent impact studies (FLATO; MAROTZKE, 2013), but requires more refined investigations. The low number of studies focusing on model development is likely associated with technical and financial limitations. Those model development studies are usually more sophisticated, requiring highly qualified human resources and appropriate infrastructure, e.g., a supercomputer (SHUKLA et al., 2010).

\section{Approach applied by the studies}

\section{Climate modelling}

The MME approach is under limited application in Brazil. Nearly half of the studies (twenty-nine) considered a single GCM (Figure 5). Twelve articles made use of the outputs from 2 GCMs, ten studies considered from 3 to 9 GCMs and four studies adopted from 10 to 19 GCMs. The use of nearly all GCMs available (more than 20) were found in nine studies. The use of several
GCM outputs combined with regionalization techniques requires specialized human resources and, in the case of RCMs, a considerable computational infrastructure (WILBY et al., 2009). The higher the quantity of GCMs used, the lower the amount of studies applying RCMs. For large sets of GCM, the most applied techniques are the ESD and the BC. Additionally, RCMs are prone to systematic biases and BC is often applied (CHRISTENSEN et al., 2008). In the case of Brazil, this approach was considered in fifteen studies.

The higher the variety of regionalization techniques, the more robust the study. Multiple regionalization methods $(\mathrm{GCM}+\mathrm{RCM}+\mathrm{ESD}$ and $\mathrm{GCM}+\mathrm{RCM}+\mathrm{BC}+\mathrm{ESD})$ were found in two studies, but their limitation comes from the low number of GCM outputs used.

The results suggest limitations in the acquisition of GCM data as well as in the access to computational infrastructure to run sophisticated models. We recognize that the acquisition of large amounts of GCM data is not a trivial task. It requires specialized technical support and considerable computational resources. In addition, we noticed gaps in the communication of scientific information. The definition of regionalization techniques is often inaccurate. We also detected differences in the terminology used by climatologists and hydrologists.

We found that different types of climate model products were applied (Figure 6). The CMIP3 GCMs were first launched in 2005 (MEEHL et al., 2007), but the first application in Brazil is dated from 2008. The increase in the use of CMIP3 was observed only from 2011. The use of the fifth version (CMIP5) was first published three years after its launching in 2012. Since 2015, there has been a replacement of the previous version to the newest

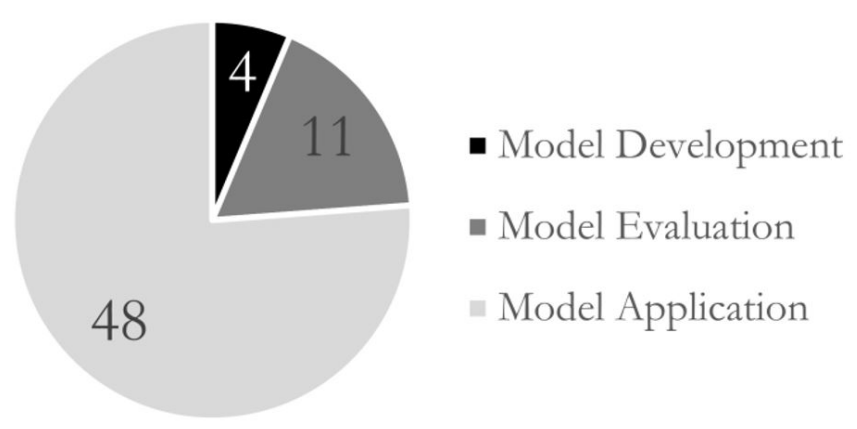

Figure 4. Quantity of studies by purpose.

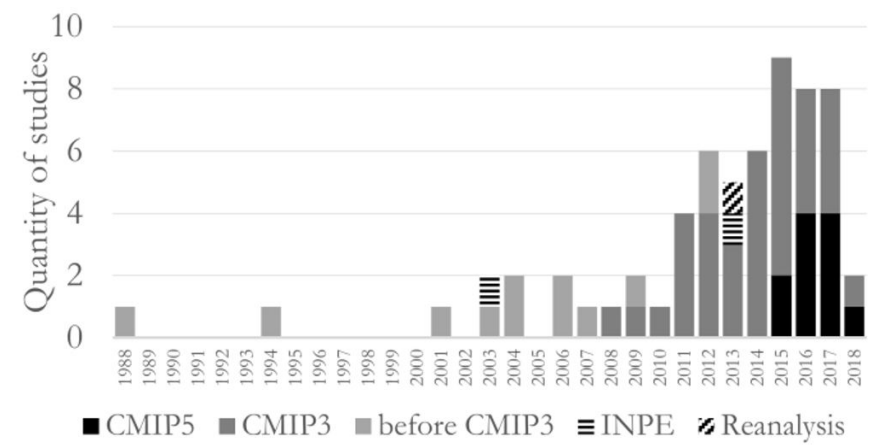

Figure 5. Quantity of articles by amount of GCMs and regionalization techniques applied. All studies are included. 


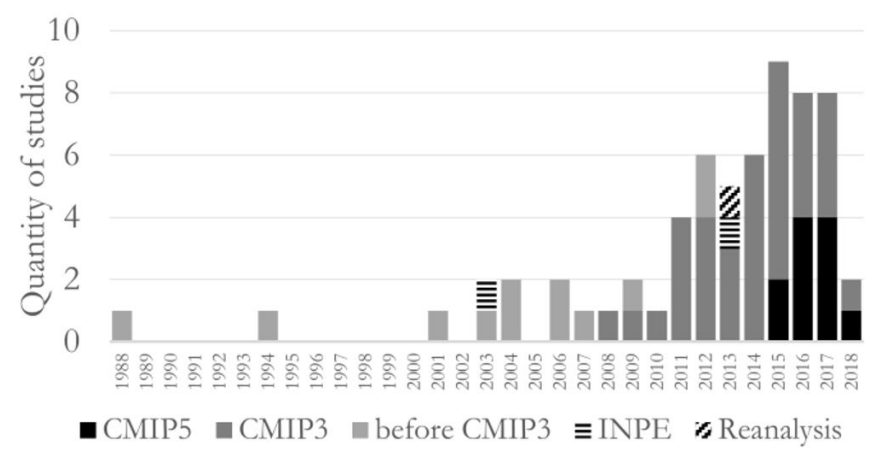

Figure 6. Quantity of articles by climate model products per year. All studies are included.

one. Some studies considered a Brazilian model developed by the Instituto Nacional de Pesquisas Espaciais (INPE) and the NCEP Reanalysis, but their aim was for model evaluation purposes, not for model application in impact assessments.

Typology of regionalization techniques

Figure 7 shows that the most applied RCM was the Eta-CPTEC (CHOU et al., 2012). Its popularity is attributed to the successful collaboration of the Centro de Previsão do Tempo e Estudos Climáticos (CPTEC/INPE) with other research groups. Seven out of eighteen studies included CPTEC researchers as co-authors. The HadRM3P (MARENGO et al., 2009) and RSM-NCEP (JUANG; KANAMITSU, 1994) were applied in five studies each. The HadRM3P together with PROMES-UCLM (CASTRO; FERNÁNDEZ; GAERTNER, 1993), RCA-SMHI (SAMUELSSON et al., 2011) and RegCM3 (GIORGI; MARINUCCI; BATES, 1993), are part of the Coordinated Regional Climate Downscaling Experiment (CORDEX, JACOB et al., 2007). The initiative aims to provide outputs of downscaling models for impact studies at the regional scale. However, it is not clear whether the application of RCMs is associated with the CORDEX South America's efforts.

In terms of ESD, the most adopted method was the Model for the Assessment of Greenhouse-Gas Induced Climate Change/Scenario Generator (MAGICC/SCENGEN; WIGLEY, 2008). The projections of global-mean temperature produced by the MAGICC drives the regional climate change scenario generator SCENGEN. This pattern scaling method appears in IPCC reports since 1990 (JEGANATHAN; ANDIMUTHU, 2013) and was applied in four studies in Brazil. The ClimGen (TODD et al., 2011), also a pattern scaling technique, was considered in three studies. Intended for impact assessments in the agriculture, ClimGen was used in Brazil for hydropower, drinking water supply and conservation purposes. The STatistical Analogue Resampling Scheme (STARS, WERNER; GERSTENGARBE, 1997) was applied in three studies as well.

The most applied BC techniques were the DCF and the QM, both in seventeen studies. The DCF is widely applied in hydrological impact assessments (JIMÉNEZ CISNEROS et al., 2014). The method can rapidly provide a broad set of bias adjusted projections, but its simplicity implies to critical limitations, e.g., changes

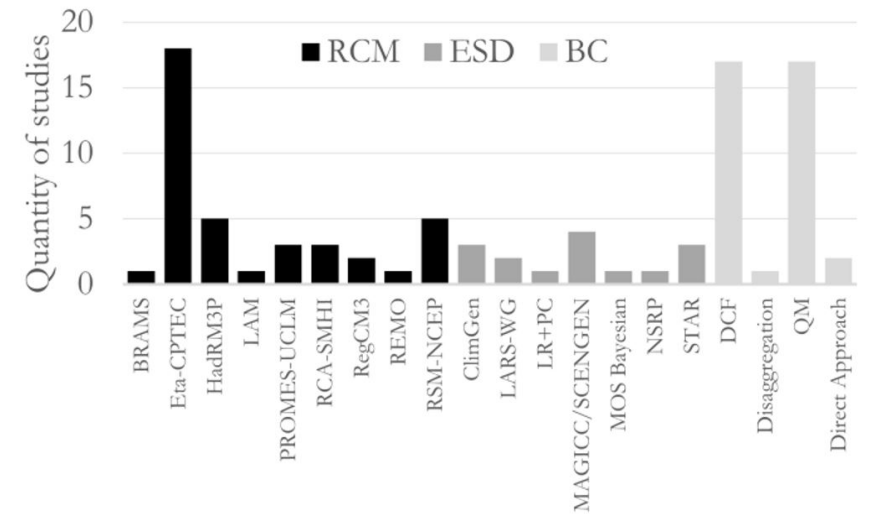

Figure 7. Quantity of studies by regionalization models and techniques. All studies are included.

in temporal variability are neglected (FOWLER; BLENKINSOP; TEBALDI, 2007). The QM is more sophisticated and has demonstrated a considerable added value in providing corrected projections. When the aim is to adjust the statistical distribution of the data, that is the recommended method. However, the tail of the distribution is often distorted by QM and extreme events can be misrepresented (MARAUN et al., 2010). Additionally, QM does not directly consider time-dependent statistics such as consecutive dry days (ADDOR; SEIBERT, 2014). The majority of the studies in Brazil using QM are not related to extreme events or time-dependent indices, showing a coherence in the application of the technique. It is important to highlight that most studies used a distinct definition for QM (i.e., 'transformation of the frequency distribution', 'percentile-to-percentile', 'correction of probability density function', 'correction of probability density function', 'adjustment of cumulative distribution functions' and 'probability mapping').

\section{Hydrological Modelling}

The Instituto de Pesquisas Hidráulicas (IPH) is the institution in Brazil leading the topic of modelling in water resources. Figure 8 shoes that the Modelo de Grandes Bacias (MGB-IPH, COLLISCHONN et al., 2007) was the most applied hydrological model (ten studies). The Soil Moisture Accounting Procedure (SMAP, LOPES; BRAGA JUNIOR; CONEJO, 1981) was applied in nine studies and the very popular Soil and Water Assessment Tool (SWAT, SANTHI et al., 2006) was used in seven studies. Three studies made use of the Modelo Hidrológico Distribuído (MHD-INPE, TOMASELLA et al., 2011). Many other models were applied in one or two studies. It is important to highlight the efforts of Pereira, Moraes and Uvo (2014), who implemented a two-way coupling, or inline hydrological-atmospheric system, for regional scale modelling. In this case, the Brazilian Regional Atmospheric Modeling System (BRAMS, FREITAS et al., 2009) was coupled to the MGB-IPH. Most studies adopt offline modelling approaches, even though feedback effects can play a substantial role. The coupled regional modelling is physically more consistent than the offline version, but it demands enormous computational capacity and technical knowledge. In addition, crucial aspects leave 


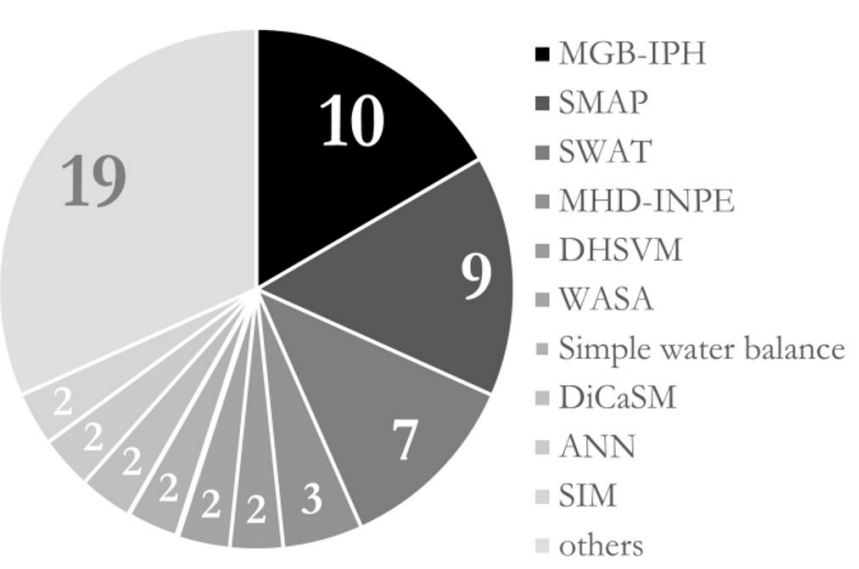

Figure 8. Type of hydrological models used. All studies are included.

room for improvement, especially regarding the parameterization schemes. These models are in development phase rather than being applied in impact assessments. Robust and reliable estimates are still unlikely to be obtained (BUT'TS et al., 2014). Therefore, the study of PEREIRA; MORAES; UVO (2014) deserves merit by pioneering the development of a two-way coupling approach in Brazil.

\section{Studies addressing 'model evaluation'}

Several studies demonstrated that RCMs significantly improve rainfall estimates (ALVES; CAMPOS; SERVAIN, 2012; BLOCK et al., 2009; BRAGA et al., 2013; KRUK; VENDRAME; CHOU, 2013; KWON et al., 2012; LIMA; ALVES, 2009; OLIVEIRA; PEDROLLO; CASTRO, 2015a, 2015b; PEREIRA; MORAES; UVO, 2014). That's also valid when RCM is coupled inline with a hydrological model (PEREIRA; MORAES; UVO, 2014). The added value of ESDs was confirmed by Coelho et al. (2006) and Block et al., (2009), who used Bayesian Approach and Linear Regression with Principal Components respectively. The QM is very useful for adjusting the statistical distribution of the data (ALVES; CAMPOS; SERVAIN, 2012; LIMA; ALVES, 2009; TUCCI et al., 2003), while the DCF is questionable. When combined with RCM outputs, Braga et al. (2013) and Oliveira, Pedrollo and Castro (2015a) demonstrated advantages in applying DCF for monthly scale. On the other hand, when intended for high resolution studies, Kruk, Vendrame and Chou (2013) concluded that the technique is useless. Oliveira, Pedrollo and Castro (2015a) shows no evidence of the superiority of one bias correction technique over the others.

Some authors (BRAGA et al., 2013; TUCCI et al., 2003) suggest that the information extracted from GCMs without regionalization may be useful for impact assessments. The superiority of the MME approach is unquestionable. Block et al. (2009) demonstrated the benefits of MME, not only in the quantification of uncertainties, but also in error compensation. Another important aspect is the propagation of uncertainties along the modelling chain. Block et al. (2009) states that uncertainty analysis "remains a formidable challenge". The uncertainties associated with climate modelling and regionalization are usually thought to be greater than a) Aspects of Comprehensiveness

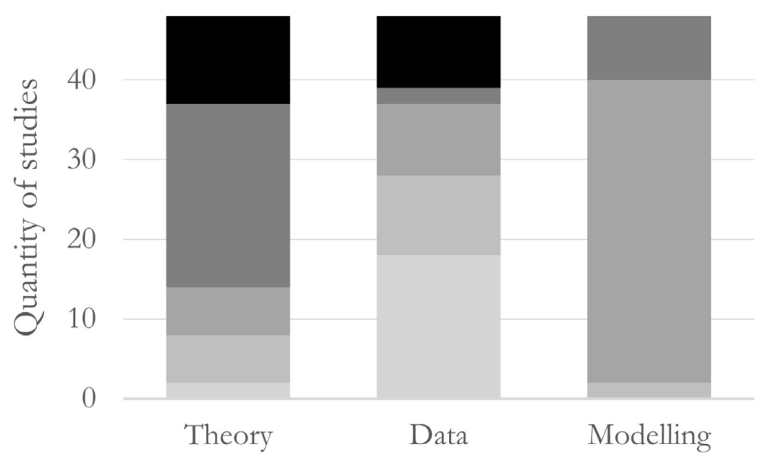

b)

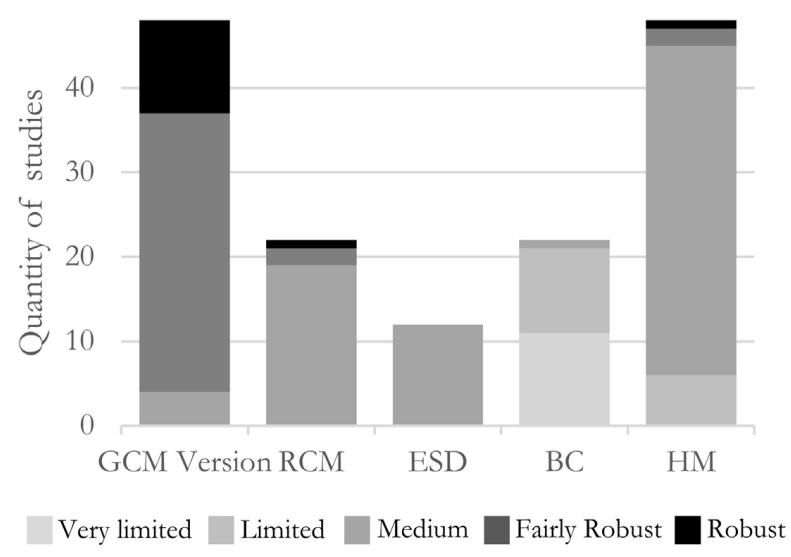

Figure 9. Classification of: a) aspects of comprehensiveness and b) the sub-aspects of modelling. Only 'model application' studies are included.

that of hydrological modelling (KWON et al., 2012). Block et al. (2009) highlight the application of weighting methods to generate probabilistic estimates of GCM outputs. Kwon et al. (2012) and Tucci et al. (2003) emphasize the need for a super-ensemble approach in order to quantify the uncertainties related to the structure of all model types in the modelling chain.

\section{Studies addressing 'model application'}

Studies addressing 'model application' in the context of impacts assessments were evaluated considering their level of comprehensiveness (see section 'Level of comprehensiveness of the studies'). Under this framework, the theoretical foundation is usually fairly robust or robust, with thirty-four studies adopting the regionalization procedure consistent with the state-of-the-art (Figure 9a). Drawbacks are clear when comes to data. More than a half of the articles (twenty-seven studies) adopted up to two GCMs. Only eleven studies made use of a considerable quantity of GCM outputs ( $\geq 10$ members). In terms of modelling, the great majority of the studies (thirty-eight articles) are at medium level of comprehensiveness; whereas two studies are classified as limited. The GCM versions used in the studies are consistent with the available datasets. Thirty-three studies used outputs from the CMIP3 database and eleven studies applied the last version (Figure 9b). Concerning the RCM, ESD and HM, the majority of the studies 
used models that are consistent with the recommendations of the scientific community. Eight studies are classified as fairly robust in terms of modelling procedure, mainly due to the application of more than one model in the regionalization and/or hydrologic modelling procedure. In terms of $\mathrm{BC}$, eleven documents are considered very limited due to the application of DCF, a technique which is under low reliability (MARAUN; WIDMANN, 2018). Ten studies are limited due the application of QM and one study is at medium level due to the application of two $\mathrm{BC}$ methods combined. The aspects of comprehensiveness reveal important scientific issues in dealing with the impacts of climate change on the Brazilian water resources. Although strongly recommended, the MME approach is under limited application.

\section{CONCLUSIONS}

With 63 scientific articles, we identified that great attention was given to the integration of climate models into hydrological models in Brazil in this decade. The majority of the studies are about the Paraná hydrographic region and focus on hydropower and drinking water supply sectors. The second region of greatest interest is the Atlântico Nordeste Oriental, which has the drinking water supply as the most relevant sector. Despite the high population density and economic importance, the Atlântico Sudeste region is under represented.

The hydropower sector is of highest interest. Nearly two thirds of the electricity production in the country depends on the water resources. Including information about the potential impacts of climate change represents an enormous challenge for the establishment of robust operational plans and resilient designs. The second sector under highest interest is the drinking water supply. Issues are mainly related to the quantity of water in the semi-arid region and in urban areas. Despite the great socioeconomic relevance, the flood risk reduction was addressed in very few studies.

The theoretical basis and the modelling procedure adopted in the studies are usually consistent with the state-of-the-art. Drawbacks are clear when it comes to the application of a large ensemble of GCMs. A realistic reason for that is the lack of technical capacity and limited access to computational infrastructure to assimilate and postprocess GCM data. There is also a demand to equalize the understanding of the concepts and terms used among climatologists, hydrologists and stakeholders. General lexicon and guidelines are recommended to match the understanding of the concepts and the terms used in the integration of climate models into hydrological models.

The comprehensiveness of studies can be improved by adding more models and, perhaps, using more sophisticated BC techniques. However, we strongly recommend that the modelling procedure adopted should be user-tailored. In other words, the evaluation and the application of models should be based on the needs of the end-users and process-informed rather than looking for e.g., the highest resolution (MARAUN et al., 2017). The evaluation of the degree of comprehensiveness proved to be a valuable analysis to guide actions to improve the subject in Brazil. We suggest to increase accessibility to GCM databases and enhance capacity on postprocessing of data. One way to bridge this gap is to build capacity across research institutions and universities. Given the challenges that Brazilian science is facing, we recommend the synchronization of efforts among research institutions. Research should prioritize regions and sectors according to e.g., their level of vulnerability and observed ongoing changes. That represents an outstanding opportunity for initiatives such as the Brazilian Network on Global Climate Change Research (Rede Clima) and, consequently, for a more effective use of climate change impacts information by decision-makers in Brazil.

\section{ACKNOWLEDGMENTS}

We acknowledge the Brazilian National Council for Scientific and Technological Development (CNPq) for funding this study (Grant Number 150768/2017-6 and 159528/2018-6)

\section{REFERENCES}

ABRAMOPOULOS, F.; ROSENZWEIG, C.; CHOUDHURY, B. Improved Ground Hydrology Calculations for Global Climate Models (GCMs): Soil Water Movement and Evapotranspiration. Journal of Climate, v. 1, n. 9, p. 921-941, 1988. http://dx.doi. org/10.1175/1520-0442(1988)001<0921:IGHCFG>2.0.CO;2.

ADAM, K. N.; COLLISCHONN, W. Análise dos impactos de mudanças climáticas nos regimes de precipitação e vazão na bacia hidrográfica do rio Ibicuí. Revista Brasileira de Recursos Hídricos, v. 18, n. 3, p. 69-79, 2013. http:/ /dx.doi.org/10.21168/rbrh.v18n3. p69-79.

ADAM, K. N.; FAN, F. M.; PONTES, P. R.; BRAVO, J. M.; COLLISCHONN, W. Mudanças climáticas e vazões extremas na Bacia do Rio Paraná. Revista Brasileira de Recursos Hídricos, v. 20, n. 4, p. 999-1007, 2015. http://dx.doi.org/10.21168/rbrh. v20n4.p999-1007.

ADDOR, N.; SEIBERT, J. Bias correction for hydrological impact studies - beyond the daily perspective. Hydrological Processes, v. 28, n. 17, p. 4823-4828, 2014. http://dx.doi.org/10.1002/hyp.10238.

ALVARENGA, L. A.; MELLO, C. R.; COLOMBO, A.; CUARTAS, L. A.; CHOU, S. C. Hydrological responses to climate changes in a headwater watershed. Ciência e Agrotecnologia, v. 40, n. 6, p. 647657, 2016. http://dx.doi.org/10.1590/1413-70542016406027716.

ALVES, J. M. B.; CAMPOS, J. N. B.; SERVAIN, J. Reservoir management using coupled atmospheric and hydrological models: The Brazilian Semi-Arid Case. Water Resources Management, v. 26, n. 5 , p. 1365-1385, 2012. http://dx.doi.org/10.1007/s11269-011-9963-2.

ANA - AGÊNCIA NACIONAL DE ÁGUAS. Atlas Brasil Abastecimento Urbano de Água. Brasília, DF: ANA, 2010.

ANA - AGÊNCIA NACIONAL DE ÁGUAS. Conjuntura dos recursos hídricos no Brasil: 2013. Brasília, DF: ANA, 2013.

ANA - AGÊNCIA NACIONAL DE ÁGUAS. Encarte Especial sobre a Crise Hidrica. Conjuntura dos recursos hidricos no Brasil. Informe 2014. Brasília, DF: ANA, 2014. 
ANA - AGÊNCIA NACIONAL DE ÁGUAS. ProjetoLEGADO: Uma agenda para aperfeiçoamento dos marcos constitucional, legal e infralegal da gestão de águas no Brasil. Preparação para o 80 fórum mundial da água. Brasília, DF: ANA, 2017. Available in: <http:/ / arquivos.ana.gov.br/ projetos/legado/DocumentoBase-VersaoZero.4_20171110.pdf>.

ANEEL - AGÊNCIA NACIONAL DE ENERGIA ELÉTRICA. Matriz de Energia Elétrica. Available from: <http://www2.aneel. gov.br/aplicacoes/capacidadebrasil/OperacaoCapacidadeBrasil. cfm>. Access on: 13 jul. 2017.

ARAÚJO, J. C.; DÖLL, P.; GÜNTNER, A.; KROL, M.; ABREU, C. B. R.; HAUSCHILD, M.; MENDIONDO, E. M. Water Scarcity Under Scenarios for Global Climate Change and Regional Development in Semiarid Northeastern Brazil. Water International, v. 29, n. 2, p. 209-220, 2004. http://dx.doi.org/10.1080/02508060408691770.

ARROIO JUNIOR, P.; MAUAD, F. Simulação dos Impactos das mudanças climáticas na vazão da Bacia do Ribeirão do Feijão - SP. Revista Brasileira de Recursos Hídricos, v. 20, n. 3, p. 741-751, 2015. http://dx.doi.org/10.21168/rbrh.v20n3.p741-751.

BLÁZQUEZ, J.; NUÑEZ, M. N. Analysis of uncertainties in future climate projections for South America: comparison of WCRP-CMIP3 and WCRP-CMIP5 models. Climate Dynamics, v. 41, n. 3-4, p. 1039-1056, 2013. http://dx.doi.org/10.1007/ s00382-012-1489-7.

BLOCK, P. J.; SOUZA FILHO, F. A.; SUN, L.; KWON, H. H. A streamflow forecasting framework using multiple climate and hydrological models. Journal of the American Water Resources Association, v. 45, n. 4, p. 828-843, 2009. http://dx.doi.org/10.1111/j.17521688.2009.00327.x.

BORGES, P. A.; CHAFFE, P. B. Towards a comprehensive characterization of evidence in synthesis assessments: climate change impacts on the Brazilian water resources. Climatic Change, v. 153, p. 1-21, 2019. https://dx.doi.org/10.1007/s10584-019-02430-9

BRAGA, A. C. F. M.; SILVA, R. M.; SANTOS, C. A. G.; GALVÃO, C. O.; NOBRE, P. Downscaling of a global climate model for estimation of runoff, sediment yield and dam storage: A case study of Pirapama basin, Brazil. Journal of Hydrology, v. 498, p. 46-58, 2013. http://dx.doi.org/10.1016/j.jhydrol.2013.06.007.

BRAVO, J. M.; COLLISCHONN, W.; PAZ, A. R.; ALLASIA, D.; DOMECQ, F. Impact of projected climate change on hydrologic regime of the Upper Paraguay River basin. Climatic Change, v. 127, n. 1, p. 27-41, 2014. http://dx.doi.org/10.1007/s10584-013-0816-2.

BRASIL. Ministério do Meio Ambiente. Secretaria de Recursos Hídricos. Caderno da Região Hidrográfica do Paraná. Brasília, DF: MMA, 2006a. Available from: <www.mma.gov.br/estruturas/161/_ publicacao/161_publicacao03032011023747.pdf>. Access on: 10 ago. 2017.

BRASIL. Ministério do Meio Ambiente. Secretaria de Recursos Hídricos. Caderno da Região Hidrográfica Atlantico Nordeste Oriental.
Brasília: MMA, 2006b. Available from: <www.mma.gov.br/ estruturas/161/_publicacao/161_publicacao03032011024510. pdf $>$. Access on: 10 ago. 2017.

BRASIL. Ministério do Meio Ambiente. Secretaria de Recursos Hídricos. Caderno da Região Hidrográfica Amazônica. Brasília: MMA, 2006c. Available from: <www.mma.gov.br/estruturas/161/_ publicacao/161_publicacao03032011024915.pdf>. Access on: 10 ago. 2017.

BRASIL. Ministério do Meio Ambiente. Secretaria de Recursos Hídricos. Caderno da Região Hidrográfica do Tocantins-Araguaia. Brasília: MMA, 2006d. Available from: <www.mma.gov.br/ estruturas/161/_publicacao/161_publicacao02032011035943. pdf>. Access on: 10 ago. 2017.

BRASIL. Ministério do Meio Ambiente. Secretaria de Recursos Hídricos. Caderno da Região Hidrográfica do São Francisco. Brasília: MMA, 2006e. Available from: <www.mma.gov.br/estruturas/161/_ publicacao/161_publicacao03032011023538.pdf>. Access on: 10 ago. 2017.

BRASIL. Ministério do Meio Ambiente. Secretaria de Recursos Hídricos. Caderno da Região Hidrográfica do Uruguai. Brasília: MMA, 2006f. Available from: <www.mma.gov.br/estruturas/161/_ publicacao/161_publicacao03032011023025.pdf>. Access on: 10 ago. 2017.

BRASIL. Ministério do Meio Ambiente. Secretaria de Recursos Hídricos. Caderno da Região Hidrográfica Atlântico Leste. Brasília: MMA, 2006g. Available from: <www.mma.gov.br/estruturas/161/_ publicacao/161_publicacao03032011024710.pdf>. Access on: 10 ago. 2017.

BRASIL. Ministério do Meio Ambiente. Secretaria de Recursos Hídricos. Caderno da Região Hidrográfica Atlântico Sul. Brasília: MMA, 2006h. Available from: <www.mma.gov.br/estruturas/161/_ publicacao/161_publicacao03032011024106.pdf>. Access on: 10 ago. 2017.

BRASIL. Ministério do Meio Ambiente. Secretaria de Recursos Hídricos. Caderno da Região Hidrográfica do Paraguai. Brasília: MMA, 2006i. Available from: <http://www.mma.gov.br/estruturas/161/_ publicacao/161_publicacao03032011023853.pdf>. Access on: 10 ago. 2017.

BRASIL. Ministério do Meio Ambiente. Secretaria de Recursos Hídricos. Caderno da Região Hidrográfica Atlântico Sudeste. Brasília: MMA, 2006j. Available from: <www.mma.gov.br/estruturas/161/_ publicacao/161_publicacao03032011024223.pdf>. Access on: 10 ago. 2017.

BRASIL. Ministério do Meio Ambiente. Secretaria de Recursos Hídricos. Caderno da Região Hidrográfica Parnaíba. Brasília: MMA, 2006k. Available from: <http://www.mma.gov.br/estruturas/161/_ publicacao/161_publicacao03032011023605.pdf>. Access on: 10 ago. 2017. 
BRASIL. Ministério do Meio Ambiente. Secretaria de Recursos Hídricos. Caderno da Região Hidrográfica Atlântico Nordeste Ocidental. Brasília: MMA, 2006l. Available from: < http:/ / www.mma.gov.br/ estruturas/161/_publicacao/161_publicacao03032011024629. pdf>. Access on: 10 ago. 2017.

BRASIL. Ministério do Meio Ambiente. Secretaria de Recursos Hídricos. National Adaptation Plan to Climate Change: volume I: general strategy. Brasília: MMA, 2016. Available from: <http://www.mma. gov.br/images/arquivo/80182/PNA_Volume\%20I_EN.pdf $>$. Access on: 10 ago. 2017.

BUTTS, M.; DREWS, M.; LARSEN, M. A. D.; LERER, S.; RASMUSSEN, S. H.; GROOSS, J.; OVERGAARD, J.; REFSGAARD, J. C.; CHRISTENSEN, O. B.; CHRISTENSEN, J. H. Embedding complex hydrology in the regional climate system - Dynamic coupling across different modelling domains. Advances in Water Resources, v. 74, p. 166-184, 2014. http://dx.doi.org/10.1016/j. advwatres.2014.09.004.

CASTRO, M.; FERNÁNDEZ, C.; GAERTNER, M. A. Description of a mesoscale atmospheric numerical model. In: Díaz, J. I.; Lions, J. L. (Eds.). Mathematics, climate and environment. Paris: Masson. p. 230-253, 1993.

CEPED UFSC - CENTRO UNIVERSITÁRIO DE ESTUDOS E PESQUISAS SOBRE DESASTRES. UNIVERSIDADE FEDERAL DE SANTA CATARINA. Atlas brasileiro de desastres naturais 1991 a 2012: volume Brasil. Florianópolis: CEPED UFSC, 2013. Available in: <https://s2id.mi.gov.br/paginas/atlas/>. Accessed on: 12 jun. 2017.

CEPED UFSC - CENTRO UNIVERSITÁRIO DE ESTUDOS E PESQUISAS SOBRE DESASTRES. UNIVERSIDADE FEDERAL DE SANTA CATARINA; WORLD BANK. Relatório de danos materiais e prejuizos decorrentes de desastres naturais no Brasil: 1995 - 2014. Florianópolis: CEPED UFSC; World Bank, 2016. Available from: <http://www.ceped.ufsc.br/wp-content/ uploads/2017/01/111703-WP-CEPEDRelatoriosdeDanoslayoutPUBLIC-PORTUGUESE-ABSTRACT-SENT.pdf> . Access on: 12 jun. 2017.

CHAGAS, V. B. P.; CHAFFE, P. L. B. The Role of Land Cover in the Propagation of Rainfall Into Streamflow Trends. Water Resources Research, v. 54, n. 9, p. 5986-6004, 2018. http://dx.doi. org/10.1029/2018WR022947.

CHOU, S. C.; MARENGO, J. A.; LYRA, A. A.; SUEIRO, G.; PESQUERO, J. F.; ALVES, L. M.; KAY, G.; BETTS, R.; CHAGAS, D. J.; GOMES, J. L.; BUSTAMANTE, J. F.; TAVARES, P. Downscaling of South America present climate driven by 4-member HadCM3 runs. Climate Dynamics, v. 38, n. 3-4, p. 635-653, 2012. http:// dx.doi.org/10.1007/s00382-011-1002-8.

CHRISTENSEN, J. H.; BOBERG, F.; CHRISTENSEN, O. B.; LUCAS-PICHER, P. On the need for bias correction of regional climate change projections of temperature and precipitation.
Geophysical Research Letters, v. 35, n. 20, p. 30, 2008. http://dx.doi. org/10.1029/2008GL035694.

COELHO, C. A. S.; STEPHENSON, D. B.; DOBLAS-REYES, F. J.; BALMASEDA, M.; GUETTER, A.; VAN OLDENBORGH, G. J. A Bayesian approach for multi-model downscaling: Seasonal forecasting of regional rainfall and river flows in South America. Meteorological Applications, v. 13, n. 01, p. 73, 2006. http://dx.doi. org/10.1017/S1350482705002045.

COELHO, C. A. S.; DE OLIVEIRA, C. P.; AMBRIZZI, T.; REBOITA, M. S.; CARPENEDO, C. B.; CAMPOS, J. L. P. S.; TOMAZIELLO, A. C. N.; PAMPUCH, L. A.; CUSTÓDIO, M. S.; DUTRA, L. M. M.; DA ROCHA, R. P.; REHBEIN, A. The 2014 southeast Brazil austral summer drought: regional scale mechanisms and teleconnections. Climate Dynamics, v. 46, n. 11-12, p. 3737-3752, 2016. http://dx.doi.org/10.1007/s00382-015-2800-1.

COLLISCHONN, W.; ALLASIA, D.; SILVA, B. C.; TUCCI, C. E. $\mathrm{M}$. The MGB-IPH model for large-scale rainfall-runoff modelling. Hydrological Sciences Journal, v. 52, n. 5, p. 878-895, 2007. http:// dx.doi.org/10.1623/hysj.52.5.878.

COOK, B.; ZENG, N.; YOON, J.-H. Will Amazonia Dry Out? Magnitude and causes of change from IPCC Climate Model Projections. Earth Interactions, v. 16, n. 3, p. 1-27, 2012. http:// dx.doi.org/10.1175/2011EI398.1.

DE OLIVEIRA, V. A.; MELLO, C. R.; VIOLA, M. R.; SRINIVASAN, R. Assessment of climate change impacts on streamflow and hydropower potential in the headwater region of the Grande river basin, Southeastern Brazil: CLIMATE CHANGE IMPACTS ON STREAMFLOW AND HYDROPOWER POTENTIAL. International Journal of Climatology, v. 37, n. 15, p. 5005-5023, 2017. http://dx.doi.org/10.1002/joc.5138.

DE QUEIROZ, A. R.; MARANGON LIMA, L. M.; MARANGON LIMA, J. W.; DA SILVA, B. C.; SCIANNI, L. A. Climate change impacts in the energy supply of the Brazilian hydro-dominant power system. Renewable Energy, v. 99, p. 379-389, 2016. http:// dx.doi.org/10.1016/j.renene.2016.07.022.

EHRET, U.; ZEHE, E.; WULFMEYER, V.; WARRACH-SAGI, K.; LIEBERT, J. Should we apply bias correction to global and regional climate model. Hydrology and Earth System Sciences, v. 16, n. 9 , p. 3391-3404, 2012. http://dx.doi.org/10.5194/hess-16-3391-2012.

FERNANDES, R. O.; SILVEIRA, C. S.; STUDART, T. M. C.; SOUZA FILHO, F. A. Reservoir yield intercomparison of large dams in Jaguaribe Basin-CE in climate change scenarios. Revista Brasileira de Recursos Hidricos, v. 22, n. 11, 2017. http://dx.doi. org/10.1590/2318-0331.011716033.

FILL, H. D.; MINE, M. R. M.; FERNANDES, C. V. S.; BESSA, M. R. Impact of climate change on hydropower production within the La Plata Basin. International Journal of River Basin Management, v. 11, n. 4, p. 449-462, 2013. http://dx.doi.org/10.1080/157151 24.2013.865638. 
FLATO, G.; MAROTZKE, J. Evaluation of Climate Models. In: STOCKER, T. F.; QIN D.; PLATTNER G. K.; TIGNOR M.; ALLEN S. K.; BOSCHUNG J.; NAUELS A.; XIA Y.; BEX V. and MIDGLEY P.M. (Eds.). Climate Change 2013: The Physical Science Basis. Contribution of Working Group I to the Fifth Assessment Report of the Intergovernmental Panel on Climate Change. Cambridge.: Cambridge University Press, 2013. p. 741-866.

FOWLER, H. J.; BLENKINSOP, S.; TEBALDI, C. Linking climate change modelling to impacts studies: recent advances in downscaling techniques for hydrological modelling. International Journal of Climatology, v. 27, n. 12, p. 1547-1578, 2007. http:// dx.doi.org/10.1002/joc.1556.

FREITAS, S. R.; LONGO, K. M.; SILVA DIAS, M. A. F.; CHATFIELD, R.; SILVA DIAS, P.; ARTAXO, P.; ANDREAE, M. O.; GRELL, G.; RODRIGUES, L. F.; FAZENDA, A.; PANETTA, J. The Coupled Aerosol and Tracer Transport model to the Brazilian developments on the Regional Atmospheric Modeling System (CATT-BRAMS) - Part 1: Model description and evaluation. Atmospheric Chemistry and Physics, v. 9, n. 8, p. 2843-2861, 2009. http://dx.doi.org/10.5194/acp-9-2843-2009.

GIORGI, F.; MARINUCCI, M. R.; BATES, G. T. Development of a Second-Generation Regional Climate Model (RegCM2). Part I: Boundary-Layer and Radiative Transfer Processes. Monthly Weather Review, v. 121, n. 10, p. 2794-2813, 1993. http://dx.doi. org/10.1175/1520-0493(1993)121<2794:DOASGR>2.0.CO;2.

GONDIM, R. S.; DE CASTRO, M. A.; TEIXEIRA, A. S.; EVANGELISTA, S. R. M. Impactos das mudanças climáticas na demanda de irrigação da bananeira na Bacia do Jaguaribe. Revista Brasileira de Engenharia Agrícola e Ambiental, v. 15, n. 6, p. 594-600, 2011. http://dx.doi.org/10.1590/S1415-43662011000600009.

GONDIM, R.; SILVEIRA, C.; SOUZA FILHO, F.; VASCONCELOS, F.; CID, D. Climate change impacts on water demand and availability using CMIP5 models in the Jaguaribe basin, semi-arid Brazil. Environmental Earth Sciences, v. 77, n. 15, p. 550, 2018. http://dx.doi. org/10.1007/s12665-018-7723-9.

GOSLING, S. N.; TAYLOR, R. G.; ARNELL, N. W.; TODD, M. C. A comparative analysis of projected impacts of climate change on river runoff from global and catchment-scale hydrological models. Hydrology and Earth System Sciences, v. 15, n. 1, p. 279-294, 2011. http:/ /dx.doi.org/10.5194/hess-15-279-2011.

GUIMBERTEAU, M.; CIAIS, P.; DUCHARNE, A.; BOISIER, J. P.; DUTRA AGUIAR, A. P.; BIEMANS, H.; DE DEURWAERDER, H.; GALBRAITH, D.; KRUIJT, B.; LANGERWISCH, F.; POVEDA, G.; RAMMIG, A.; RODRIGUEZ, D. A.; TEJADA, G.; THONICKE, K.; VON RANDOW, C.; VON RANDOW, R. C. S.; ZHANG, K.; VERBEECK, H. Impacts of future deforestation and climate change on the hydrology of the Amazon Basin: a multi-model analysis with a new set of land-cover change scenarios. Hydrology and Earth System Sciences, v. 21, n. 3, p. 1455-1475, 2017. http://dx.doi.org/10.5194/hess-21-1455-2017.
GULIZIA, C.; CAMILLONI, I. Comparative analysis of the ability of a set of CMIP3 and CMIP5 global climate models to represent precipitation in South America. International Journal of Climatology, v. 35, n. 4, p. 583-595, 2015. http://dx.doi.org/10.1002/joc.4005.

HARZING, A.-W.; ALAKANGAS, S. Google Scholar, Scopus and the Web of Science: a longitudinal and cross-disciplinary comparison. Scientometrics, v. 106, n. 2, p. 787-804, 2016. http:// dx.doi.org/10.1007/s11192-015-1798-9.

HIRATA, R.; CONICELLI, B. P. Groundwater resources in Brazil: a review of possible impacts caused by climate change. Anais da Academia Brasileira de Ciências, v. 84, n. 2, p. 297-312, 2012. http:/ / dx.doi.org/10.1590/S0001-37652012005000037.

HO, J. T.; THOMPSON, J. R.; BRIERLEY, C. Projections of hydrology in the Tocantins-Araguaia Basin, Brazil: uncertainty assessment using the CMIP5 ensemble. Hydrological Sciences Journal, v. 61, n. 3, p. 551-567, 2016. http://dx.doi.org/10.1080/026266 67.2015.1057513.

IPCC - INTERGOVERNMENTAL PANEL ON CLIMATE CHANGE. Managing the risks of extreme events and disasters to advance climate change adaption: special report of the Intergovernmental Panel on Climate Change. New York: Cambridge University Press, 2012.

JACOB, D.; BÄRRING, L.; CHRISTENSEN, O. B.; CHRISTENSEN, J. H.; CASTRO, M.; DÉQUÉ, M.; GIORGI, F.; HAGEMANN, S.; HIRSCHI, M.; JONES, R.; KJELLSTRÖM, E.; LENDERINK, G.; ROCKEL, B.; SÁNCHEZ, E.; SCHÄR, C.; SENEVIRATNE, S. I.; SOMOT, S.; VAN ULDEN, A.; VAN DEN HURK, B. An inter-comparison of regional climate models for Europe: model performance in present-day climate. Climatic Change, v. 81, n. S1, p. 31-52, 2007. http://dx.doi.org/10.1007/s10584-006-9213-4.

JEGANATHAN, A.; ANDIMUTHU, R. Developing climate change scenarios for Tamil Nadu, India using MAGICC/SCENGEN. Theoretical and Applied Climatology, v. 114, n. 3-4, p. 705-714, 2013. http://dx.doi.org/10.1007/s00704-013-0871-7.

JIMÉNEZ CISNEROS, B. E., et al. Freshwater resources. In: FIELD, C. B., BARROS V. R., DOKKEN D. J.; MACH K. J.; MASTRANDREA M. D.; BILIR T. E.; CHATTERJEE M.; EBI K. L.; ESTRADA Y. O.; GENOVA R. C.; GIRMA B.; KISSEL E. S.; LEVY A. N.; MACCRACKEN S.; MASTRANDREA P. R. and WHITE L. L. (Eds.). Climate Change 2014: Impacts, Adaptation, and Vulnerability. Part A: Global and Sectoral Aspects. Contribution of Working Group II to the Fifth Assessment Report of the Intergovernmental Panel on Climate Change. Cambridge: Cambridge University Press, 2014. p. 229-269.

JUANG, H. M. H.; KANAMITSU, M. The NMC Nested Regional Spectral Model. Monthly Weather Review, v. 122, n. 1, p. 3-26, 1994. http://dx.doi.org/10.1175/1520-0493(1994)122<0003:TNNR $\mathrm{SM}>2.0 . \mathrm{CO} ; 2$.

KROL, M.; JAEGER, A.; BRONSTERT, A.; KRYWKOW, J. The Semi-arid Integrated Model (SIM), a regional integrated model 
assessing water availability, vulnerability of ecosystems and society in NE-Brazil. Physics and Chemistry of the Earth. Part B: Hydrology, Oceans and Atmosphere, v. 26, n. 7-8, p. 529-533, 2001. http://dx.doi. org/10.1016/S1464-1909(01)00045-4.

KROL, M. S.; BRONSTERT, A. Regional integrated modelling of climate change impacts on natural resources and resource usage in semi-arid Northeast Brazil. Environmental Modelling \& Software, v. 22, n. 2, p. 259-268, 2007. http://dx.doi.org/10.1016/j. envsoft.2005.07.022.

KROL, M. S.; JAEGER, A.; BRONSTERT, A.; GÜNTNER, A. Integrated modelling of climate, water, soil, agricultural and socioeconomic processes: A general introduction of the methodology and some exemplary results from the semi-arid north-east of Brazil. Journal of Hydrology (Amsterdam), v. 328, n. 3-4, p. 417-431, 2006. http://dx.doi.org/10.1016/j.jhydrol.2005.12.021.

KRUK, N. S.; VENDRAME, Í. F.; CHOU, S. C. Coupling a Mesoscale Atmospheric Model with a Distributed Hydrological Model Applied to a Watershed in Southeast Brazil. Journal of Hydrologic Engineering, v. 18, n. 1, p. 58-65, 2013. http://dx.doi. org/10.1061/(ASCE)HE.1943-5584.0000606.

KUNDZEWICZ, Z. W.; KRYSANOVA, V.; BENESTAD, R. E.; HOV, Ø.; PINIEWSKI, M.; OTTO, I. M. Uncertainty in climate change impacts on water resources. Environmental Science \& Policy, v. 79, p. 1-8, 2018. http://dx.doi.org/10.1016/j.envsci.2017.10.008.

KWON, H.-H.; ASSIS DE SOUZA FILHO, F.; BLOCK, P.; SUN, L.; LALL, U.; REIS JUNIOR, D. S. Uncertainty assessment of hydrologic and climate forecast models in Northeastern Brazil. Hydrological Processes, v. 26, n. 25, p. 3875-3885, 2012. http://dx.doi. org/10.1002/hyp.8433.

LAMPARTER, G.; NOBREGA, R. L. B.; KOVACS, K.; AMORIM, R. S.; GEROLD, G. Modelling hydrological impacts of agricultural expansion in two macro-catchments in Southern Amazonia, Brazil. Regional Environmental Change, v. 31, 2016. http://dx.doi. org/10.1007/s10113-016-1015-2.

LIMA, J. P. R.; ALVES, M. B. Um estudo de downscaling dinâmico de precipitação intrasazonal acoplado a modelo chuva-vazão na bacia hidrográfica alto-médio São Francisco. Revista Brasileira de Meteorologia, v. 24, n. 3, p. 323-338, 2009. http://dx.doi.org/10.1590/ S0102-77862009000300006.

LOPES, J. E. G.; BRAGA JUNIOR, B. P. F.; CONEJO, J. G. L. A. Simulação hidrológica: aplicações de um modelo simplificado. In: SIMPÓSIO BRASILEIRO DE HIDROLOGIA E RECURSOS HÍDRICOS, 4., 1981, Fortaleza. Anais... Fortaleza: SBRH, 1981. p. $42-62$.

MARAUN, D.; WETTERHALL, F.; IRESON, A. M.; CHANDLER, R. E.; KENDON, E. J.; WIDMANN, M.; BRIENEN, S.; RUST, H. W.; SAUTER, T.; THEMESSL, M.; VENEMA, V. K. C.; CHUN, K. P.; GOODESS, C. M.; JONES, R. G.; ONOF, C.; VRAC, M.; THIELE-EICH, I. Precipitation downscaling under climate change: Recent developments to bridge the gap between dynamical models and the end user. Reviews of Geophysics, v. 48, n. 3, p. RG3003, 2010. http://dx.doi.org/10.1029/2009RG000314.

MARAUN, D.; SHEPHERD, T. G.; WIDMANN, M.; ZAPPA, G.; WALTON, D.; GUTIÉRREZ, J. M.; HAGEMANN, S.; RICHTER, I.; SOARES, P. M. M.; HALL, A.; MEARNS, L. O. Towards process-informed bias correction of climate change simulations. Nature Climate Change, v. 7, n. 11, p. 664-773, 2017. http://dx.doi.org/10.1038/nclimate3418.

MARAUN, D.; WIDMANN, M. Statistical Downscaling and Bias Correction for Climate Research. 1. ed. Cambridge: Cambridge University Press, 2018. http://dx.doi.org/10.1017/9781107588783

MARENGO, J. A.; CHOU, S. C.; KAY, G.; ALVES, L. M.; PESQUERO, J. F.; SOARES, W. R.; SANTOS, D. C.; LYRA, A. A.; SUEIRO, G.; BETTS, R.; CHAGAS, D. J.; GOMES, J. L.; BUSTAMANTE, J. F.; TAVARES, P. Development of regional future climate change scenarios in South America using the Eta CPTEC/HadCM3 climate change projections: climatology and regional analyses for the Amazon, São Francisco and the Paraná River basins. Climate Dynamics, v. 38, n. 9-10, p. 1829-1848, 2012. http://dx.doi.org/10.1007/s00382-011-1155-5.

MARENGO, J. A.; JONES, R.; ALVES, L. M.; VALVERDE, M. C. Future change of temperature and precipitation extremes in South America as derived from the PRECIS regional climate modeling system. International Journal of Climatology, v. 29, n. 15, p. 2241-2255, 2009. http://dx.doi.org/10.1002/joc.1863.

MARENGO, J. A.; MILLER, J. R.; RUSSELL, G. L.; ROSENZWEIG, C. E.; ABRAMOPOULOS, F. Calculations of river-runoff in the GISS GGM: impact of a new land-surface parameterization and runoff routing model on the hydrology of the Amazon River. Climate Dynamics, v. 10, n. 6, p. 349-361, 1994. http://dx.doi. org/10.1007/BF00228032.

MASTRANDREA, M. D.; MACH, K. J.; PLATTNER, G.-K.; EDENHOFER, O.; STOCKER, T. F.; FIELD, C. B.; EBI, K. L.; MATSCHOSS, P. R. The IPCC AR5 guidance note on consistent treatment of uncertainties: a common approach across the working groups. Climatic Change, v. 108, n. 4, p. 675-691, 2011. http:// dx.doi.org/10.1007/s10584-011-0178-6.

MEDEIROS, Y. D. P. Análise dos impactos das mudanças climáticas em região semi-árida. Revista Brasileira de Recursos Hídricos, v. 8, n. 2, p. 127-136, 2003. http://dx.doi.org/10.21168/rbrh.v8n2.p127-136.

MEEHL, G. A.; COVEY, C.; DELWORTH, T.; LATIF, M.; MCAVANEY, B.; MITCHELL, J. F. B.; STOUFFER, R. J.; TAYLOR, K. E. THE WCRP CMIP3 Multimodel Dataset: A New Era in Climate Change Research. Bulletin of the American Meteorological Society, v. 88, n. 9, p. 1383-1394, 2007. http://dx.doi. org/10.1175/BAMS-88-9-1383.

MELLO, E. L.; OLIVEIRA, F. A.; PRUSKI, F. F.; FIGUEIREDO, J. C. Effect of the climate change on the water availability in the 
Paracatu river basin. Engenharia Agrícola, v. 28, n. 4, p. 635-644, 2008. http://dx.doi.org/10.1590/S0100-69162008000400003.

MELO, D. C. D.; MARIN, I. S. P.; WENDLAND, E. Water budget comparison of global climate models and experimental data in Onça Creek basin, Brazil. Proceedings of the International Association of Hydrological Sciences, v. 364, p. 70-75, 2014. http:// dx.doi.org/10.5194/piahs-364-70-2014.

MELO, D. C. D.; WENDLAND, E. Shallow aquifer response to climate change scenarios in a small catchment in the Guarani Aquifer outcrop zone. Anais da Academia Brasileira de Ciências, v. 89, n. 1, p. 391-406, 2017. Supplement. http://dx.doi.org/10.1590/00013765201720160264.

MENDES, C. A. B.; BELUCO, A.; CANALES, F. A. Some important uncertainties related to climate change in projections for the Brazilian hydropower expansion in the Amazon. Energy, v. 141, p. 123-138, 2017. http://dx.doi.org/10.1016/j.energy.2017.09.071.

MOHOR, G. S.; MENDIONDO, E. M. Economic indicators of hydrologic drought insurance under water demand and climate change scenarios in a Brazilian context. Ecological Economics, v. 140, p. 66-78, 2017. http://dx.doi.org/10.1016/j.ecolecon.2017.04.014.

MOHOR, G. S.; RODRIGUEZ, D. A.; TOMASELLA, J.; SIQUEIRA JÚNIOR, J. L. Exploratory analyses for the assessment of climate change impacts on the energy production in an Amazon run-ofriver hydropower plant. Journal of Hydrology: Regional Studies, v. 4, p. 41-59, 2015. http://dx.doi.org/10.1016/j.ejrh.2015.04.003.

MONTENEGRO, A.; RAGAB, R. Hydrological response of a Brazilian semi-arid catchment to different land use and climate change scenarios: a modelling study. Hydrological Processes, v. 24, n. 19, p. 2705-2723, 2010. http://dx.doi.org/10.1002/hyp.7825.

MONTENEGRO, S.; RAGAB, R. Impact of possible climate and land use changes in the semi arid regions: A case study from North Eastern Brazil. Journal of Hydrology, v. 434-435, p. 55-68, 2012. http://dx.doi.org/10.1016/j.jhydrol.2012.02.036.

NOBRE, C. A.; SAMPAIO, G.; BORMA, L. S.; CASTILLARUBIO, J. C.; SILVA, J. S.; CARDOSO, M. Land-use and climate change risks in the Amazon and the need of a novel sustainable development paradigm. Proceedings of the National Academy of Sciences of the United States of America, v. 113, n. 39, p. 10759-10768, 2016. http://dx.doi.org/10.1073/pnas.1605516113.

NÓBREGA, M. T.; COLLISCHONN, W.; TUCCI, C. E. M.; PAZ, A. R. Uncertainty in climate change impacts on water resources in the Rio Grande Basin, Brazil. Hydrology and Earth System Sciences, v. 15, n. 2, p. 585-595, 2011. http://dx.doi.org/10.5194/hess-15585-2011.

OliveirA, G. G.; PEDROLlO, O. C.; CASTRO, N. M. R. As incertezas associadas às condições climáticas obtidas pelo modelo Eta CPTEC/HadCM3: avaliação comparativa entre os dados simulados e observados de precipitação, evapotranspiração e vazão na bacia hidrográfica do rio Ijuí, Brasil. Revista Brasileira de Meteorologia, v. 30, n. 1, p. 101-121, 2015a. http://dx.doi. org/10.1590/0102-778620140041.

OliveirA, G. G.; PEDROLlO, O. C.; CASTRO, N. M. R. Stochastic approach to analyzing the uncertainties and possible changes in the availability of water in the future based on scenarios of climate change. Hydrology and Earth System Sciences, v. 19, n. 8, p. 3585-3604, 2015b. http://dx.doi.org/10.5194/hess-19-3585-2015.

PERAZZOLI, M.; PINHEIRO, A.; KAUFMANN, V. Assessing the impact of climate change scenarios on water resources in southern Brazil. Hydrological Sciences Journal, v. 58, n. 1, p. 77-87, 2013. http://dx.doi.org/10.1080/02626667.2012.742195.

PEREIRA, F. F; MORAES, M. A. E.; UVO, C. B. Implementation of a two-way coupled atmospheric-hydrological system for environmental modeling at regional scale. Hydrology Research, v. 45, n. 3, p. 504-514, 2014. http://dx.doi.org/10.2166/nh.2013.335.

PINHEIRO, A.; GRACIANO, R. L. G.; KAUFMANN, V. Simulating effects of climate scenarios on hydrological processes in southern Brazil using a lysimeter. International Journal of Climatology, v. 33, n. 9, p. 2206-2214, 2013. http://dx.doi.org/10.1002/joc.3591.

PINHEIRO, E.; VAN LIER, Q.; BEZERRA, A. Hydrology of a Water $\square$ Limited Forest under Climate Change Scenarios: The Case of the Caatinga Biome, Brazil. Forests, v. 8, n. 3, p. 62, 2017. http://dx.doi.org/10.3390/f8030062.

POPESCU, I.; BRANDIMARTE, L.; PEVIANI, M. Effects of climate change over energy production in La Plata Basin. International Journal of River Basin Management, v. 12, n. 4, p. 319327, 2014. http://dx.doi.org/10.1080/15715124.2014.917317.

RAMOS IENSEN, I. R.; BAUER SCHULTZ, G.; SANTOS, I. Simulation of hydrosedimentological impacts caused by climate change in the Apucaraninha River watershed, southern Brazil. Proceedings of the International Association of Hydrological Sciences, v. 367, p. 366-373, 2015. http://dx.doi.org/10.5194/piahs-367-366-2015.

RANDALL, D. A.; WOOD, R. A. Climate Models and Their Evaluation. In: SOLOMON, S.; QIN D.; MANNING M.; CHEN Z.; MARQUIS M.; AVERYT K. B.; TIGNOR M. and MILLER H. L. (Eds.). Climate Change 2007: The Physical Science Basis. Contribution of Working Group I to the Fourth Assessment Report of the Intergovernmental Panel on Climate Change. Cambridge: Cambridge University Press, 2007. p. 589-662.

RIBEIRO JÚNIOR, L.; ZUFFO, A.; SILVA, B. Development of a tool for hydroeletric reservoir operation with multiple uses considering effects of climate changes. Case study of Furnas HPP. Revista Brasileira de Recursos Hídricos, v. 21, n. 2, p. 300-313, 2016. http://dx.doi.org/10.21168/rbrh.v21n2.p300-313.

RIBEIRO NETO, A.; PAZ, A. R.; MARENGO, J. A.; CHOU, S. C. Hydrological Processes and Climate Change in Hydrographic 
Regions of Brazil. Journal of Water Resource and Protection, v. 08, n. 12, p. 1103-1127, 2016. http://dx.doi.org/10.4236/jwarp.2016.812087.

RIBEIRO NETO, A.; SCOTT, C. A.; LIMA, E. A.; MONTENEGRO, S.; CIRILO, J. A. Infrastructure sufficiency in meeting water demand under climate-induced socio-hydrological transition in the urbanizing Capibaribe River basin - Brazil. Hydrology and Earth System Sciences, v. 18, n. 9, p. 3449-3459, 2014. http://dx.doi. org/10.5194/hess-18-3449-2014.

RIVAROLA SOSA, J. M.; BRANDANI, G.; DIBARI, C.; MORIONDO, M.; FERRISE, R.; TROMBI, G.; BINDI, M. Climate change impact on the hydrological balance of the Itaipu Basin. Meteorological Applications, v. 18, n. 2, p. 163-170, 2011. http:// dx.doi.org/10.1002/met.213.

ROSENZWEIG, C.; STRZEPEK, K. M.; MAJOR, D. C.; IGLESIAS, A.; YATES, D. N.; MCCLUSKEY, A.; HILLEL, D. Water resources for agriculture in a changing climate: international case studies. Global Environmental Change, v. 14, n. 4, p. 345-360, 2004. http://dx.doi.org/10.1016/j.gloenvcha.2004.09.003.

SALAZAR, L. F.; NOBRE, C. A.; OYAMA, M. D. Climate change consequences on the biome distribution in tropical South America. Geophysical Research Letters, v. 34, n. 9, p. 16, 2007. http://dx.doi. org/10.1029/2007GL029695.

SAMUELSSON, P.; JONES, C. G.; WILL'EN, U.; ULLERSTIG, A.; GOLLVIK, S.; HANSSON, U.; JANSSON, E.; KJELLSTRO“M, C.; NIKULIN, G.; WYSER, K. The Rossby Centre Regional Climate model RCA3: model description and performance. Tellus A. Dynamic Meteorology and Oceanography, v. 63, n. 1, p. 4-23, 2011. http://dx.doi.org/10.1111/j.1600-0870.2010.00478.x.

SANTHI, C.; SRINIVASAN, R.; ARNOLD, J. G.; WILLIAMS, J. R. A modeling approach to evaluate the impacts of water quality management plans implemented in a watershed in Texas. Environmental Modelling \& Software, v. 21, n. 8, p. 1141-1157, 2006. http://dx.doi.org/10.1016/j.envsoft.2005.05.013.

SHUKLA, J.; PALMER, T. N.; HAGEDORN, R.; HOSKINS, B.; KINTER, J.; MAROTZKE, J.; MILLER, M.; SLINGO, J. Toward a New Generation of World Climate Research and Computing Facilities. Bulletin of the American Meteorological Society, v. 91, n. 10, p. 1407-1412, 2010. http://dx.doi.org/10.1175/2010BAMS2900.1.

SILVEIRA, C. S.; FILHO, F.; LOPES, J.; BARBOSA, P.; TIEZZI, R. Análise das projeções de vazões nas bacias do setor elétrico brasileiro usando dados do IPCC-AR4 para o século XXI. Revista Brasileira de Recursos Hídricos, v. 19, n. 4, p. 59-71, 2014. http:// dx.doi.org/10.21168/rbrh.v19n4.p59-71.

SILVEIRA, C. S.; SOUZA FILHO, F. A.; VASCONCELOS JÚNIOR, F. C. Streamflow projections for the Brazilian hydropower sector from RCP scenarios. Journal of Water and Climate Change, v. 8, n. 1, p. 114-126, 2017. http://dx.doi.org/10.2166/wcc.2016.052.

SIQUEIRA JÚNIOR, J. L.; TOMASELLA, J.; RODRIGUEZ, D. A. Impacts of future climatic and land cover changes on the hydrological regime of the Madeira River basin. Climatic Change, v. 129 , n. 1-2, p. 117-129, 2015. http://dx.doi.org/10.1007/ s10584-015-1338-x.

SORRIBAS, M. V.; PAIVA, R. C. D.; MELACK, J. M.; BRAVO, J. M.; JONES, C.; CARVALHO, L.; BEIGHLEY, E.; FORSBERG, B.; COSTA, M. H. Projections of climate change effects on discharge and inundation in the Amazon basin. Climatic Change, v. 136, n. 3-4, p. 555-570, 2016. http://dx.doi.org/10.1007/s10584-016-1640-2.

STERLING, S. M.; DUCHARNE, A.; POLCHER, J. The impact of global land-cover change on the terrestrial water cycle. Nature Climate Change, v. 3, n. 4, p. 385-390, 2012. http://dx.doi. org/10.1038/nclimate1690.

TAYLOR, K. E.; STOUFFER, R. J.; MEEHL, G. A. An Overview of CMIP5 and the Experiment Design. Bulletin of the American Meteorological Society, v. 93, n. 4, p. 485-498, 2012. http://dx.doi. org/10.1175/BAMS-D-11-00094.1.

TEBALDI, C.; KNUTTI, R. The use of the multi-model ensemble in probabilistic climate projections. Philosophical Transactions of the Royal Society A: Mathematical, Physical and Engineering Sciences, v. 365, n. 1857, p. 2053-2075, 2007. https://dx.doi.org/10.1098/ rsta.2007.2076

TEJADAS, B. E.; BRAVO, J. M.; SANAGIOTTTO, D. G.; TASSI, R.; MARQUES, D. M. L. Projeções de vazão afluente à lagoa mangueira com base em cenários de mudanças climáticas. Revista Brasileira de Meteorologia, v. 31, n. 3, p. 262-272, 2016. http://dx.doi. org/10.1590/0102-778631320150139.

TEUTSCHBEIN, C.; SEIBERT, J. Bias correction of regional climate model simulations for hydrological climate-change impact studies: Review and evaluation of different methods. Journal of Hydrology, v. 456-457, p. 12-29, 2012. http://dx.doi.org/10.1016/j. jhydrol.2012.05.052.

TODD, M. C.; TAYLOR, R. G.; OSBORN, T. J.; KINGSTON, D. G.; ARNELL, N. W.; GOSLING, S. N. Uncertainty in climate change impacts on basin-scale freshwater resources - preface to the special issue: the QUEST-GSI methodology and synthesis of results. Hydrology and Earth System Sciences, v. 15, n. 3, p. 1035-1046, 2011. http:/ /dx.doi.org/10.5194/hess-15-1035-2011.

TOMASELLA, J.; BORMA, L. S.; MARENGO, J. A.; RODRIGUEZ, D. A.; CUARTAS, L. A.; NOBRE, C.; PRADO, M. C. R. The droughts of 1996-1997 and 2004-2005 in Amazonia: hydrological response in the river main-stem. Hydrological Processes, v. 25, n. 8, p. 1228-1242, 2011. http://dx.doi.org/10.1002/hyp.7889.

TORRES, R. R.; MARENGO, J. A. Climate change hotspots over South America: from CMIP3 to CMIP5 multi-model datasets. Theoretical and Applied Climatology, v. 117, n. 3-4, p. 579-587, 2014. http://dx.doi.org/10.1007/s00704-013-1030-x.

TUCCI, C. E. M.; CLARKE, R. T.; COLLISCHONN, W.; SILVA DIAS, P. L.; OLIVEIRA, G. S. Long-term flow forecasts based on climate and hydrologic modeling: Uruguay River 
basin. Water Resources Research, v. 39, n. 7, 2003. http://dx.doi. org/10.1029/2003WR002074.

VALÉRIO, E.; JÚNIOR, C. Avaliação dos efeitos de mudanças climáticas no regime hidrológico da bacia do rio Paraguaçu, BA / Evaluation of the effects of climate change on the hydrological response of the Paraguaçu river basin. Revista Brasileira de Recursos Hídricos, v. 20, n. 4, p. 872-887, 2015. http://dx.doi.org/10.21168/ rbrh.v20n4.p872-887.

VIOLA, M. R.; MELLO, C. R.; CHOU, S. C.; YANAGI, S. N.; GOMES, J. L. Assessing climate change impacts on Upper Grande River Basin hydrology, Southeast Brazil. International Journal of Climatology, v. 35, n. 6, p. 1054-1068, 2015. http://dx.doi. org/10.1002/joc.4038.

WERNER, P.; GERSTENGARBE, F. Proposal for the development of climate scenarios. Climate Research, v. 8, p. 171-182, 1997. http:/ / dx.doi.org/10.3354/cr008171.

WIGLEY, T. M. L. MAGICC/SCENGEN 5.3: user manual (version 2). Colorado: National Center for Atmospheric Research (NCAR), 2008.

WILBY, R. L.; TRONI, J.; BIOT, Y.; TEDD, L.; HEWITSON, B. C.; SMITH, D. M.; SUTTON, R. T. A review of climate risk information for adaptation and development planning. International
Journal of Climatology, v. 29, n. 9, p. 1193-1215, 2009. http://dx.doi. org/10.1002/joc.1839.

ZANINELLI, P. G.; MENÉNDEZ, C. G.; FALCO, M.; LÓPEZFRANCA, N.; CARRIL, A. F. Future hydroclimatological changes in South America based on an ensemble of regional climate models. Climate Dynamics, v. 52, n. 1-2, p. 819-830, 2018.

\section{SUPPLEMENTARY MATERIAL}

Supplementary material accompanies this paper.

Table S1. Articles list database.

This material is available as part of the online article from http:/ / www.scielo.br/rbrh.

\section{Author contributions}

Pablo Borges de Amorim: Article's search and gathering, selection of articles, conceptualization of the approach, translation of the article's information to the matrix, analysis, preparation of the figures, discussion and manuscript preparation.

Pedro Luiz Borges Chaffe: Article's search and gathering, selection of articles, conceptualization of the approach, double-check of the matrix, discussion and revision of the manuscript 